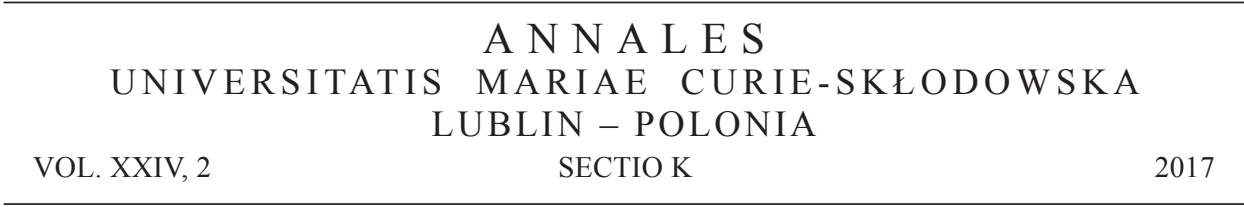

Wydział Politologii Uniwersytetu Marii Curie-Skłodowskiej w Lublinie

\title{
Ante bellum: Uwarunkowania historyczne procesów dezintegracyjnych na terytorium Socjalistycznej Federacyjnej Republiki Jugosławii i jej państw sukcesyjnych po zimnej wojnie
}

Ante bellum: Historical conditionings of disintegration processes in the territory of the Socialist Federal Republic of Yugoslavia and its successor states after the Cold War

\begin{abstract}
ABSTRAKT
W artykule przeanalizowano szerokie uwarunkowania historyczne procesów dezintegracyjnych, jakie wystąpiły po zakończeniu zimnej wojny na terytorium byłej Socjalistycznej Federacyjnej Republiki Jugosławii. Podkreślono w nim, iż w ostatniej dekadzie XX w. na obszarze jugosłowiańskim doszło do swoistego „powrotu historii”, wyrażającego się w dążeniach narodów bałkańskich do „odwrócenia” niekorzystnych procesów historycznych, „dokończenia” rozpoczętych jeszcze XIX w. procesów państwowotwórczych oraz zjednoczenia wszystkich terytoriów zamieszkiwanych współcześnie lub w przeszłości przez daną grupę etniczną w ramach własnego państwa narodowego. Wskazano także, iż skomplikowana historia regionu Bałkanów - w tym wielowiekowe rządy osmańskiej Turcji, nierozwiązane i sięgające mniej lub bardziej odległej przeszłości spory terytorialne, okresy otwartej, zbrojnej konfrontacji, ugruntowane w pamięci zbiorowej narodów Półwyspu negatywne doświadczenia wzajemnych relacji i wspólnej państwowości oraz wielokrotnie dająca o sobie znać w XIX i XX w. polityka zewnętrznego interwencjonizmu i paternalizmu - nie stanowiła wprawdzie głównego powodu dezintegracji SFRJ, ale mimo to w istotnym stopniu przyczyniła się do rozpadu federacji jugosłowiańskiej i wybuchu konfliktów zbrojnych na obszarze jej państw sukcesyjnych. Konkludując, można stwierdzić, iż „niedokończona historia” w dalszym ciągu przyczynia się do politycznej dezintegracji i niestabilności regionu oraz poważnej dysfunkcjonalności części państw pojugosłowiańskich ${ }^{1}$
\end{abstract}

Słowa kluczowe: Historia Bałkanów, rozpad Socjalistycznej Federacyjnej Republiki Jugosławii, procesy narodotwórcze i państwowotwórcze na Bałkanach, interwencje zewnętrzne w regionie Bałkanów

1 W niniejszej publikacji wykorzystano, rozwinięto i uzupełniono niektóre tezy zamieszczone w artykule Region Europy Poludniowo-Wschodniej, zamieszczonym w monografii naukowej Regiony w stosunkach międzynarodowych [Olchowski, Pawłowski 2009: 73-100]. 
Analiza procesów i wydarzeń historycznych, które miały miejsce na Bałkanach w XIX i XX w., uprawnia do stwierdzenia, że region ten cechuje się wielością aktywnych konfliktów etnicznych oraz występowaniem silnych tendencji dezintegracyjnych. Okoliczność ta spowodowała, że w literaturze naukowej i publicystyce polityczna niestabilność Bałkanów często jest uznawana za naturalną i permanentną cechę tego obszaru. W efekcie, w odniesieniu do regionu są formułowane opinie o istnieniu „kotła bałkańskiego”, „,bałkańskiego węzła gordyjskiego”, ,europejskiej beczki prochu” czy też „europejskiego epicentrum burz” oraz postrzegania Bałkanów w charakterze niemal pod każdym względem ,innej” i „dzikiej” Europy². Z kolei w stosunku do mieszkańców Półwyspu są wysuwane tezy o istnieniu sui generis „bałkańskiej mentalności”, sprzecznej z duchem Zachodu i wyrażającej poparcie dla etnicznego nacjonalizmu, politycznej nietolerancji, populizmu, rządów autorytarnych, wojny, irredenty, separatyzmu oraz prymitywnych sporów i równie prymitywnych sposobów ich rozstrzygania ${ }^{3}$. Last but not least, nierzadko też wskazuje się, że o konfliktogennym charakterze stosunków międzyetnicznych na Półwyspie Bałkańskim decyduje „zderzenie cywilizacji”, wynikające ze „ścierania” się na Bałkanach linii ,granicznych” katolicyzmu, prawosławia i islamu [Lubonja 2000: 106-107; Huntington 2004: 385-405; Čolović 2007: 5-7; Jezernik 2007: 13-40; Todorova 2008: 19-55].

2 Dominujące przez wieki - i w dalszym ciągu częściowo aktualne - pejoratywne wyobrażenie Bałkanów w kulturze Zachodu doskonale scharakteryzował Božidar Jezernik, który podkreślił, że „Bałkany przez stulecia uznawano za odległe (kulturowo) od Zachodu”, i wskazał, że jeszcze na początku XX w. dla zachodnich podróżników daleko zmitologizowane i egzotyczne „Bałkany nie były wyłącznie obszarem geograficznym, ale raczej polem walki pomiędzy Wschodem a Zachodem, Przeszłością i Teraźniejszością, pomiędzy barbarzyństwem i cywilizacją. [...] W opowieściach tych termin »Europa« pełnił funkcję kategorii analitycznej, pozwalającej używającym go wyznaczyć podziały pomiędzy Europą a Bałkanami (jako częścią Orientu) oraz stworzyć kryteria pozwalające na ocenianie tych drugich. W rezultacie Bałkany wyobrażano sobie nie jako część Europy, ale odbity obraz tego, co w stosunku do Europy było gorsze i inne. Na przykład Europę postrzegano jako aktywną, rozwiniętą, uprzemysłowioną, świecką i nowoczesną, Bałkany zaś jako pasywne, wiejskie, zacofane, pogrążone w stagnacji, przesądne, zmysłowe i nienowoczesne, $\mathrm{z}$ tendencją do despotyzmu i dalekie od postępu. Przekraczanie granic pomiędzy Europą i Bałkanami pojmowano nie jako proste przemieszczanie się z Zachodu na Wschód, ale wyprawę z cywilizacji do dziczy, z wolności do tyranii" [Jezernik 2007: IX].

3 Pavlos Hatzopoulos pisał, że zachodni sposób przedstawiania wydarzeń, które miały miejsce na Bałkanach w latach 90 . XX w., stanowił zestaw z góry przyjętych twierdzeń i obrazów, opartych na założeniu, że życie społeczne na Bałkanach pozostaje w przemożnym stopniu zdeterminowane przez ideologię nacjonalizmu. Stwierdził on również, że w świetle opinii zachodnich badaczy i publicystów ów bałkański nacjonalizm, uznawany za nieodłączną cechę regionu, stanowił bezpośrednią przyczynę ponownego pojawienia się na Bałkanach szokujących aktów przemocy oraz podstawę dla wiązania niemal każdego współczesnego wydarzenia ze skomplikowanymi doświadczeniami przeszłości. Konkludując, podkreślił on, że stworzony w ten sposób wizerunek był daleko uproszczony i przesadzony oraz nawiązywał do tradycyjnego, negatywnego obrazu Bałkanów, będących rzekomo „ziemią żyjącej przeszłości”, której mieszkańcy w tragiczny, nieprzekraczalny i niemal fatalistyczny sposób utknęli w pułapce własnej historii [Hatzopoulos 2003: 25-38]. 
Mimo iż tego rodzaju opinie pozostają $w$ jakimś stopniu uprawnione, nierzadko bywają one daleko uproszczone, a w niektórych przypadkach zdecydowanie przesadzone. Faktem jest to, że w XIX i pierwszej połowie XX w. na Bałkanach miały miejsce liczne konflikty zbrojne i zmiany terytorialne, których dynamika i gwałtowny przebieg przyczyniły się do powstania negatywnego obrazu regionu, wzmocnionego jeszcze przez dramatyczne wydarzenia, do jakich doszło na obszarze byłej Socjalistycznej Federacyjnej Republiki Jugosławii po zakończeniu zimnej wojny. Wnikliwa analiza historyczna uprawnia jednak do stwierdzenia, że dzieje polityczne Bałkanów nie są aż tak bardzo odmienne od innych regionów Europy, które w XIX i XX w. podobnie jak Bałkany - były areną upadku i fragmentacji państw, wojen, konfliktów etnicznych, sporów terytorialnych, zmiany granic, migracji czy czystek etnicznych [Todorova 2008: 79-80]. Rację ma zatem Francis Fukuyama, który stwierdził, że „olbrzymia większość państw na świecie stanowi produkt nie czystego, ale rywalizacyjnego procesu państwowotwórczego", oraz William R. Weir, który pisał, że „wojny ukształtowały Europę jak żaden inny kontynent. Historia Europy pisana jest krwią" [Fukuyama 2012: 114-115; Weir 2005: 77].

Mieszkańcy Bałkanów nie są również w żaden sposób kulturowo predestynowani do agresji, konfliktu i wojny. Wyraźnie zaakcentowała ów fakt Maria Todorova, która stwierdziła, że pojęcie „bałkańskiej tożsamości” należy do grupy najbardziej zmitologizowanych pojęć na gruncie antropologii i psychologii społecznej, a rzekomy homo balcanicus po prostu nie istnieje [Todorova 2004: 181-185]. Stwierdziła ona również, że „z całą pewnością Bałkany nie mają monopolu na barbarzyństwo" [Todorova 2008: 27]. Podobnie wskazał Stevan K. Pavlowitch, który zauważył, że sprowadzanie wojen bałkańskich do problemu mentalności narodów Półwyspu ,jest w najlepszym wypadku niebezpiecznym uproszczeniem, a w najgorszym, pozostaje na pograniczu ujęć rasistowskich" [Pavlowitch 1999: 169]. Również Tim Judah podkreślił, że wbrew obiegowym opiniom mieszkańcy Bałkanów nie różnią się od innych narodów europejskich, a ,jeśli ktoś myśli inaczej, powinien zastanowić się, dlaczego kulturalni i cywilizowani Niemcy dali się uwieść Hitlerowi i dopuścili się takich zbrodni w okresie II wojny światowej" [Judah 2009: XIV] $]^{4}$. Trudno również zaprzeczyć, że nacjonalizmy bałkańskie nie są bynajmniej zjawiskiem wyjątkowym, a zjawisko etnicznego nacjonalizmu nie dotyczy wyłącznie państw postkomunistycznej Europy Wschodniej [Pavlowitch 1999: 169]. Warto przytoczyć w tym miejscu słowa Hansa-Adolfa Jacobsena, który zwrócił uwagę na „dawne idee niemieckiego

${ }^{4}$ W podobny sposób odniósł się do powyższej kwestii w swej głęboko filozoficznej powieści Wiesław Myśliwski, który stwierdził, że „namiętności rządzą nie tylko jednostkami, także państwami i narodami, czego dowodzi historia. W równym stopniu są przyczyną najdzikszych barbarzyństw, co osiągnięć nauki i sztuki, w równym stopniu cofają ludzkość, co pchają ją naprzód". Z kolei w kontekście zbrodni niemieckich okresu II wojny światowej ustami wykreowanych postaci literackich ze zrezygnowaniem wskazał: „Taki kulturalny naród, jak tu nawet przyjdzie, miałby mordować? Wierzyć, panie, w kulturalne narody. Kulturalne, niekulturalne tak samo mordują" [Myśliwski 2013: 193, 319]. 
państwa narodowego, których urzeczywistnienie w XIX i XX wieku dało Europie więcej konfliktów niż pokoju" [Jacobsen 2000: 57].

Opinie te uprawniają zatem do wniosku, że o specyfice regionu bałkańskiego, odróżniającej Bałkany od pozostałych subregionów Europy, oraz dynamice stosunków międzynarodowych i wewnątrzpaństwowych na Bałkanach w dużym, a być może największym stopniu, decyduje - jak stwierdziła Judy Batt - swoista pułapka „niedokończonej przeszłości”" , wynikająca z kontynuacji rozpoczętych jeszcze w XIX w. procesów państwowotwórczych, nierozwiązanych i historycznych sporów terytorialnych, towarzyszących im silnych nacjonalizmów oraz aktywnych konfliktów etnicznych, które w XIX i XX w. wielokrotnie przyczyniły się do politycznej niestabilności i dezintegracji regionu oraz prowadziły do zbrojnej konfrontacji między narodami Półwyspu [Mazower 2000: 143-151; Tanty 2003: 5-6; Batt 2005: 60-65]. Powyższy wniosek odzwierciedla stwierdzenie Predraga Simicia, który podkreślił, że najbardziej powszechnym motywem siedmiu wojen (sic!) toczonych na Bałkanach w całym XX w. była „nierozwiązana kwestia narodowa”, tj. dążenie do odwrócenia niekorzystnych procesów historycznych i zjednoczenie wszystkich obszarów zamieszkiwanych przez daną grupę etniczną [Simic 2001: 20-21].

Przedstawione uwagi wstępne pozwalają wreszcie na postawienie tezy, iż szeroko definiowana (i nierzadko daleko subiektywnie interpretowana) historia regionu Bałkanów nie stanowiła wprawdzie głównej przyczyny konfliktów zbrojnych po zakończeniu zimnej wojny, ale mimo to odegrała istotną rolę w procesie dezintegracji Socjalistycznej Federacyjnej Republiki Jugosławii oraz eskalacji zbrojnej przemocy na obszarze jej państw sukcesyjnych. Ukazanie tejże roli pozostaje przedmiotem rozważań zawartych w dalszej części niniejszej publikacji.

\section{TERRA INCOGNITA: UWARUNKOWANIA GEOFIZYCZNE}

Waga stałych czynników przestrzennych od dawna znajduje istotne miejsce w wyjaśnianiu pozycji międzynarodowej i działań państw, jest uwzględniana przy analizie determinantów ich bezpieczeństwa, bogactwa i rozwoju historycznego. Uwarunkowania środowiskowe są wiązane również z szeroko definiowaną specyfiką kulturową danego terytorium (państwa, regionu czy kontynentu), a nawet uznawane za najważniejszy czynnik postępu bądź stagnacji społeczeństw [Szacki cz. I 1981: 329-343; Szacki cz. II 1981: 674; Dougherty, Pfaltzgraff, Jr. 1996: 144-159; Sur 2012: 203].

Odrzucając stanowisko skrajnego determinizmu środowiskowego, należy stwierdzić, że warunki geofizyczne regionu Bałkanów, który współcześnie obejmuje obszar dziesięciu państw, tj. Albanię, Bośnię i Hercegowinę, Bułgarię, Chorwację,

\footnotetext{
5 Milica Uvalić posłużyła się w tym kontekście pojęciem ,niedokończonego pokoju” [Uvalic 2001: 71].
} 
Czarnogórę, Grecję, Macedonię, Rumunię, Serbię i Kosowo, w naturalny sposób przyczyniają się do jego społecznej i politycznej dezintegracji. Z uwagi na liczne pasma górskie, będące charakterystycznym elementem krajobrazu Bałkanów, region ten pozostaje silnie rozczłonkowany i pozbawiony naturalnego środka ${ }^{6}$. Uwarunkowania geofizyczne przez stulecia ograniczały kontakty między mieszkańcami Półwyspu, prowadziły do powstania licznych, społecznie uświadomionych lokalnych różnic i odrębnych tożsamości oraz utrudniały wykształcenie się politycznego centrum regionu, którego na początku XXI w. obszar ten nadal jest pozbawiony. Uwarunkowania środowiskowe oraz towarzyszące im różnice etniczne, kulturowe, ekonomiczne i polityczne powodowały zatem, że przez stulecia górzyste oraz pod wieloma względami podzielone i zróżnicowane Bałkany pozostawały jednością daleko umowną i czysto geograficzną, widoczną głównie spoza regionu [Gołembski 1982: 49-53; Jelavich cz. I 2005: 15-17].

Mimo iż współcześnie, wskutek postępu technologicznego w zakresie środków komunikacji i transportu, nastąpiła znaczna ewolucja w zakresie związków między grupami społecznymi, państwami i przestrzeniami, w przypadku Bałkanów warunki środowiskowe pozostają istotnym - choć, rzecz jasna, nie najważniejszym - ograniczeniem rozwoju współpracy regionalnej ${ }^{7}$. Co więcej, brak tradycji długotrwałej, rzeczywistej i dobrowolnej integracji politycznej narodów Europy Południowo-Wschodniej, zróżnicowanie kulturowe społeczeństw bałkańskich oraz odmienny poziom ich rozwoju ekonomicznego budzą uzasadnione wątpliwości, czy w przypadku Bałkanów w ogóle zasadne jest posługiwanie się pojęciem regionu (sugerującego istnienie powiązań politycznych, gospodarczych lub cywilizacyjnych między tworzącymi go państwami), czy też par excellence jedynie obszaru w stosunkach międzynarodowych, położonego na peryferiach kontynentu europejskiego. Warto przytoczyć w tym miejscu opinię Thanosa Veremisa, który stwierdził, że daleko zróżnicowane pod względem politycznym, ekonomicznym i kulturowym Bałkany nigdy nie stanowiły zwartego regionu, a jedynym elementem, który w jakiś sposób spaja ten obszar, stanowi jego historia, a ściślej - wieki okupacji Półwyspu Bałkańskiego przez Wysoką Portę [Veremis 2001: 115].

\footnotetext{
6 Warto zwrócić uwagę, że nazwa „Bałkany” wywodzi się z języka tureckiego i określa łańcuch górski, zalesione góry, obszar surowy i skalisty itp. [Simic 2001: 20; Todorova 2008: 66].

7 Jak wskazywał w 2004 r. Svetlozar A. Andreev, „Europa Południowo-Wschodnia stanowi jedyny region w Europie, w którym stolice państw, a nawet same państwa, nie są połączone transportem kolejowym [podobnie jest w przypadku transportu lotniczego. W efekcie mieszkańcy niektórych państw bałkańskich, chcący udać się do sąsiedniego państwa drogą lotniczą, muszą odbyć lot z przesiadką w Wiedniu, co w oczywisty sposób wydłuża czas podróży i zwiększa koszty transportu - K.P.]. Sieć drogowa jest słabo rozbudowana i dość często nie przecina granic państwowych. Przed kolejnym rozszerzeniem UE w 2007 r. [...] w dalszym ciągu istnieją tylko dwa przejścia graniczne między Bułgarią i Grecją, Bułgarią i Turcją oraz Turcją i Grecją, zaś tylko jedno między Grecją i Albanią. Na przestrzeni 500 km granicy między Bułgarią i Rumunią jest tylko jeden most na Dunaju" [Andreev 2004: 384-385].
} 
Wśród uwarunkowań historycznych, które wywarły wyraźny wpływ na losy państw i narodów bałkańskich, ważne miejsce zajmuje wielosetletnia obecność na tym terytorium państwa Osmanów. Turcy osmańscy pojawili się na Bałkanach w połowie XIV w. i wykorzystując ówczesne rozbicie polityczne regionu oraz słabość Bizancjum, drogą konsekwentnego militarnego podboju oraz charakterystycznych dla ówczesnej epoki nierównoprawnych układów politycznych, na mocy których lokalni władcy feudalni zachowywali władzę, ale stawali się wasalami sułtana, doprowadzili do podporządkowania, a następnie całkowitej likwidacji istniejących na Bałkanach w okresie średniowiecza drobnych księstw feudalnych. W efekcie, przez kolejne stulecia region Bałkanów - określany czasem mianem „Turcji europejskiej” czy też „Turcji w Europie” - pozostawał częścią Pax Osmanica, co w przypadku niektórych części Półwyspu Bałkańskiego oznaczało ponad 500-letnie rządy imperium tureckiego [Malcolm 2002: 91-92; Blumi 2006: 5-6; Todorova 2008: 68; O'Shea 2009: 246-249; Jackson 2011: 38].

Przybycie Turków na Bałkany oznaczało kres średniowiecznej państwowości narodów bałkańskich oraz koniec snów o potędze i terytorialnej ekspansji władców chrześcijańskich. Nie może zatem dziwić, iż pejoratywny obraz rządów tureckich przetrwał w zbiorowej pamięci i folklorze narodów Półwyspu oraz pozostaje obecny we współczesnej historiografii państw regionu. Prawda o czasach osmańskich pozostaje jednak bardziej złożona. Istnieje bowiem wiele argumentów, by stwierdzić, że w sytuacji braku alternatywy narody bałkańskie w mniejszym lub większym stopniu wtopiły się w nową rzeczywistość polityczną i po prostu funkcjonowały w ramach wielokulturowego i wielonarodowego państwa Osmanów, które dla części mieszkańców Bałkanów niekoniecznie pozostawało czymś gorszym niż rządy średniowiecznych chrześcijańskich władców feudalnych. W efekcie podbite narody bałkańskie przez stulecia żyły obok siebie w atmosferze religijnej tolerancji, zaś pojawiające się międzyetniczne spory lub konflikty ograniczała i wymuszała praktyka codziennej koegzystencji. Sytuacja ta uległa zmianie, kiedy wraz z rozwojem politycznym narodów bałkańskich pojawił się nacjonalizm - z historycznego punktu widzenia de facto współczesny „wynalazek” - który w XIX i XX w. wywarł decydujący wpływ na relacje międzyetniczne $w$ regionie oraz polityczne losy Bałkanów i ostatecznie, w wyniku triumfu idei narodowej nad koncepcją wielonarodowego imperium, doprowadził do pojawiania się na terytorium dawnych europejskich posiadłości Turcji nowych państw narodowych ${ }^{8}$.

8 Stephen O'Shea wprost stwierdził, że ,imperium osmańskie było [...] par excellence wielonarodowe”. Podobnie wskazał Marco Jačov, który pisał, że „w XVI w., kiedy granice imperium Osmanów rozciągały się od Maroka do Oceanu Indyjskiego i Morza Kaspijskiego, a w Europie panowanie ich sięgało Dunaju, Turcy stanowili mniejszość w państwie zamieszkałym przez siedemdziesiąt dwa narody. Nie tylko ludność poddana, ale i wojsko sułtańskie było wielonarodowe i wielowyznaniowe. Na ówczesnych sztandarach armii osmańskiej obok półksiężyca pojawił się też serbski krzyż i herb Konstantynopola. Okazuje się, że liczba 
Polityczna dominacja Turków na Bałkanach niosła ze sobą również inne istotne konsekwencje. Włączone w skład państwa osmańskiego narody bałkańskie przez wieki podlegały systemowi władzy odmiennemu od tego, który obowiązywał w innych częściach Europy, i funkcjonowały w oderwaniu od głównych, europejskich prądów politycznych, ekonomicznych i kulturowych. Sytuacja ta w naturalny sposób generowała różnice między Europą przeżywającą okres Renesansu i Oświecenia oraz towarzyszących im - nierzadko rewolucyjnych - przemian politycznych, społecznych i gospodarczych, silnie związanych z kulturą W schodu Bałkanami ${ }^{9}$. W efekcie, kiedy na początku XIX w. na Półwyspie Bałkańskim pojawiły się w ograniczonym stopniu zachodnie idee polityczne i ustrojowe, większość narodów bałkańskich nie istniała w sensie politycznym, tj. nie miała własnego państwa, zaś świadomość odrębności narodowej i pragnienie własnej państwowości były faktycznie różne wśród mieszkańców regionu [Garlicka 1983: 366-367].

W świetle powyższego uprawnione pozostaje stwierdzenie, że wielowiekowe tradycje feudalnego systemu władzy, który do początku XX w. istniał w państwie osmańskim, przyczyniły się do wytworzenia na Bałkanach odmiennego od pozostałych subregionów Europy politycznego, ekonomicznego, społecznego i kulturowego tła procesów narodotwórczych i państwowotwórczych oraz względnego - w porównaniu

chrześcijan w armii była tak wielka, że uzyskali oni prawo do własnych symboli, a sułtanom zależało na tym, by wojownicy chrześsijańscy walczący w ich armii traktowali imperium jako swoje. [...] Z czasem, kiedy rola i znaczenie dostojników imperium wywodzących się z różnych grup etnicznych i wyznaniowych po przyjęciu islamu wzrosła, zmienił się też charakter państwa. $Z$ etnicznego państwa tureckiego wyrosło imperium wielonarodowe i wielowyznaniowe; dopiero kiedy rozpadło się ono po I wojnie światowej, Turcy odbudowali swoje państwo etniczne". W efekcie - jak wskazał Ismail Kadare - postrzeganie państwowości osmańskiej na Bałkanach wyłącznie jako czasu „tureckiego jarzma”, powstań zbrojnych przeciwko Turkom i nieustannej walki z okupantami jest uproszczone i błędne, ponieważ mieszkańcy regionu zarówno walczyli, jak i współpracowali z Turkami. Stwierdził on także, że wraz z rozwojem bałkańskich nacjonalizmów w świadomości zbiorowej narodów Półwyspu doszło do odrzucenia „niechlubnej” części własnej historii, związanej z pokojową koegzystencją w ramach państwa osmańskiego oraz wzmożonego akcentowania narodowego heroizmu, martyrologii i nieprzejednanego oporu własnego narodu wobec rządów tureckich na Bałkanach [Mazower 2000: 50-144; Kadare 2001: 5-7; Jačov 2005: 189-192; Jezernik 2007: XII-XIII; O'Shea 2009: 247-285, 402; Todorova 2008: 390-393; Kaltsounis 2010: 41-42].

9 Jak wskazała Maria Todorova, „w przededniu podboju przez Turków osmańskich mieszkańcy średniowiecznych Bałkanów osiągnęli wysoki stopień wyrafinowania, który stawiał ich na równi z przedstawicielami Zachodu lub nawet wyżej od nich. Pomimo politycznego rozczłonkowania półwyspu, co jest stanem typowym dla ostatnich i najbardziej zaawansowanych etapów rozwoju średniowiecznych społeczeństw feudalnych w Europie, pojawiły się oznaki wskazujące na możliwość podjęcia kroków prowadzących do konsolidacji narodów (uznawanych za protonarody), rozwoju humanizmu i kultur narodowych. $\mathrm{Z}$ tego punktu widzenia przybycie Turków osmańskich było klęską o nieporównywalnych z niczym następstwach, ponieważ przerwało naturalny rozwój społeczeństw południowo-wschodniej Europy, będący istotną i twórczą składową ogólnych przemian europejskiego humanizmu i renesansu. Wzmocnienie władzy Turków osmańskich na Bałkanach definitywnie odizolowało półwysep od biegu wydarzeń w Europie i sprawiło, że nie został objęty wpływem wielkich idei i przeobrażeń związanych z renesansem i reformacją. Wywołało ono poza tym głęboki regres kulturowy, a nawet swoistą barbaryzację i zrównanie społeczne. Najeźdźcy zniszczyli bałkańskie elity polityczne i intelektualne, fizycznie unicestwiając część arystokracji i kleru [...], zmuszając jej przedstawicieli do emigracji, a ostatecznie włączając ich we własne struktury polityczne i w ten sposób skutecznie ich wynaradawiając" [Todorova 2008: 389-390]. 
do państw i społeczeństw Europy Zachodniej i Środkowej-opóźnienia tych procesów, które w przypadku niektórych narodów bałkańskich zakończono dopiero na przełomie XIX i XX w. Okoliczność ta prowadziła do - trwających do czasów współczesnych polemik między narodami bałkańskimi, które postrzegały siebie w kategoriach narodów stricte historycznych, tj. narodów o długiej i dobrze udokumentowanej historii, szczycących się dziedzictwem własnej, wspaniałej państwowości, istniejącej przed przybyciem Turków na Bałkany oraz narodów pod każdym względem ,lepszych” od swoich najbliższych bałkańskich sąsiadów. Jednocześnie narody te odmawiały tego samego statusu - oraz prawa do spornych terytoriów - swoim rzekomo „niecywilizowanym” bałkańskim sąsiadom, uznawanym nierzadko za narody „bez historii”, tj. pozbawione doświadczeń ,prawdziwej” i historycznie udokumentowanej państwowości, bliskie etnicznie i kulturowo osmańskim zdobywcom, feudalne, zacofane, prymitywne, niezdolne do zbudowania silnego i nowoczesnego państwa, wreszcie przybyszów, którzy wskutek napływu i podboju w okresie średniowiecza lub późniejszej tureckiej okupacji Bałkanów oraz zachodzących na przestrzeni stuleci niekorzystnych procesów demograficznych zasiedlili terytoria zamieszkiwane „od najdawniejszych czasów” przez własną i uznawaną za autochtoniczną na danym obszarze grupę etniczną. Z punktu widzenia ludzi Zachodu przekonane o swej wyjątkowości narody bałkańskie były jednakże bardzo do siebie podobne i jednakowo niehistoryczne, nieeuropejskie, żyjące w bezczasie, plebejskie i bierne politycznie [Simic 2001: 28; Jezernik 2007: XIII-XIV; Paruch, Chmura 2012: 16-46; Lubonja 1999: 14-15].

\section{CASUS BELLI: KONFLIKTY INTERESÓW NARODÓW BAŁKAŃSKICH}

Rozpoczęte na początku XIX w. ,przebudzenie” narodowe mieszkańców Półwyspu oraz intensyfikacja procesów państwowotwórczych na Bałkanach w nieuchronny sposób doprowadziły do konfliktu interesów i aspiracji narodów bałkańskich ${ }^{10}$.

${ }^{10}$ Jak stwierdził Božidar Jezernik, ,w XIX wieku rozumienie koncepcji miletu [tj. administracyjnego podziału i samoidentyfikacji mieszkańców państwa ottomańskiego na podstawie o kryterium przynależności religijnej, a nie etnicznej - K.P.] uległo zmianie za sprawą wzrostu uczuć narodowych na obszarze Imperium Osmańskiego. Narodowość stała się wtedy podstawą państwowości europejskiej, a z powodu zachodniej dominacji na arenie światowej, wzajemne stosunki nie-zachodnich narodów i ich relacje z europejskimi potęgami musiały zbliżyć się do form uznawanych przez Zachód za oczywiste. Nowy duch świadomości narodowej obudził się wśród ludów zamieszkujących Imperium, a idea narodowości poczęła upowszechniać się wraz z próbą stworzenia prawa cywilnego, które zastąpiłoby kodeks religijny. Wzrost nacjonalizmu na Bałkanach doprowadził także do zwiększenia się świadomości historycznej i przejęcia z Europy Zachodniej mentalności humanistycznej odziedziczonej po Renesansie i encyklopedystach francuskich. [...] Wszystkie kraje bałkańskie gorączkowo zaangażowały się w projekt »europeizacji«. [...] Dziewiętnastowieczny nacjonalizm obudził przywiązanie do ikon tożsamości zbiorowej, folkloru, muzyki i architektury, inspirował i usprawiedliwiał powszechny ferwor, mobilizował nowo powstałe narody do szlachetnych osiągnięć. Narodowość buduje się jednak w oparciu o wykluczenie niektórych jednostek, a jego produktem ubocznym jest mniej lub bardziej jasno określony »inny«. Ponieważ Imperium Osmańskie stanowiło mozaikę rozmaitych narodów, spory były nieuniknioną konsekwencją tak zwanego przebudzenia narodowego" [Jezernik 2007: XII-XIV]. 
W pierwszym rzędzie wynikały one ze skomplikowanej sytuacji narodowościowej, będącej wynikiem zachodzących przez stulecia wymuszonych lub naturalnych procesów migracyjnych, skutkujących przemieszaniem ludności różnych wyznań i narodowości w granicach osmańskiej Turcji i habsburskich Austro-Węgier (tj. istniejących na Bałkanach dwóch wielkich imperiów wielonarodowych) oraz zmianą struktury demograficznej niektórych obszarów regionu. Wskutek tych procesów wykreślenie dokładnej mapy etnicznej Półwyspu Bałkańskiego w XIX i na początku $\mathrm{XX}$ w. stanowiło zadanie nader skomplikowane, a wypracowanie w tym zakresie akceptowalnego kompromisu politycznego między narodami bałkańskimi odnośnie do granic istniejących lub przyszłych państw narodowych stało się w praktyce nieosiągalne. Sytuacja ta w naturalny sposób antagonizowała narody bałkańskie, które uznawały te same terytoria za część swego wyłącznego i subiektywnie definiowanego terytorium etnicznego, będącego wskutek krzywdzących („niesprawiedliwych”) procesów historycznych i demograficznych we władaniu wrogiej grupy etnicznej ${ }^{11}$. Co więcej, powstałe w XIX w. wyraźnie nacjonalistyczne elity intelektualne i polityczne narodów bałkańskich w procesie budowy nowoczesnej tożsamości narodowej oraz $\mathrm{w}$ formułowanych programach politycznych otwarcie odwoływały się do idei zjednoczenia narodowego, zakładającego unifikację wszystkich terytoriów zamieszkiwanych przez własną grupę etniczną oraz odbudowę „wielkiego państwa”, tj. restytucji jego kształtu terytorialnego z okresu największej historycznej świetności. Przywoływane w tym celu argumenty wskazujące na ,historyczne prawa” narodów bałkańskich do określonych terytoriów były jednak często dyskusyjne, a dodatkowo w oczywisty sposób ignorowały istniejącą rzeczywistość, a więc fakt, iż trwające przez setki lat procesy demograficzne w istotnym stopniu zmieniły i skomplikowały układ stosunków narodowościowych na Półwyspie Bałkańskim ${ }^{12}$.

Konsekwencją „zderzenia” zachodzących na siebie aspiracji i roszczeń terytorialnych stało się upowszechnienie postaw nacjonalistycznych, rewizjonistycznych i militarystycznych, polityzacja elementów kulturowych (w tym kwestii przynależności religijnej) oraz narastanie konfliktów etnicznych. W XIX i w pierwszej

${ }^{11}$ Pojęcie „terytorium etniczne” definiuje obszar uważany przez daną grupę za przynależny wyłącznie tej wspólnocie etnicznej. Szczególnie konfliktogenne sytuacje mają miejsce, kiedy kilka grup uważa ten sam obszar za własne terytorium etniczne. Przekonanie o istnieniu terytorium etnicznego stanowi niezwykle silny motyw do jego obrony, a w sytuacji kiedy jest ono zamieszkiwane przez obce grupy etniczne, do jego „wyzwolenia”, dokonywanego zwykle za pomocą militarnej siły i brutalnych czystek etnicznych [Mucha 1996: 34-35].

${ }^{12}$ Mieczysław Tanty wskazał, że zrodzone w XIX w. ideologie narodowe mieszkańców Półwyspu (panhellenizm, jugoslawizm, panrumunizm, panbułgaryzm i panalbanizm) odwoływały się do mniej lub bardziej skrywanej chęci implementacji jednostronnych rozwiązań militarnych lub obrony korzystnego status quo, co skutkowało postrzeganiem działań i aspiracji innych narodów bałkańskich w charakterze zagrożenia oraz zawieraniem jedynie doraźnych sojuszy, które - jak w przypadku dwóch wojen bałkańskich (1912-1913) - nierzadko ulegały szybkiemu odwróceniu. Świadomość sprzeczności interesów narodów Półwyspu prowadziła zatem do tego, że - jak stwierdziła Barbara Jelavich - na Bałkanach „rewolucje narodowe [z XIX i początku XX w. - K.P.] [...] dokonywały się niezależnie, przy stosunkowo słabej współpracy między poszczególnymi nacjami bałkańskimi” [Tanty 2003: 6; Jelavich cz. I 2005: 10]. 
połowie XX w. państwa i narody bałkańskie wielokrotnie starały się militarnie lub z pozycji siły (tj. przez politykę dyskryminacji, czystek etnicznych, wymuszonej emigracji lub wewnątrzpaństwowej kolonizacji) rozstrzygnąć istniejące problemy narodowościowe oraz spory terytorialne, ale w większości przypadków, z uwagi na ograniczającą politykę mocarstw europejskich oraz obiektywną słabość państwowości bałkańskich, działania te zakończyły się niepowodzeniem lub jedynie częściowym sukcesem. W efekcie, w okresie międzywojennym (1918-1941) podstawowym problemem Bałkanów pozostawały nierozwiązane spory międzypaństwowe i wynikające z podziałów etnicznych antagonizmy wewnątrzpaństwowe, skutecznie podsycane przez faszystowskie Włochy i Niemcy - mocarstwa zewnętrzne, dążące do zmiany układu sił w Europie, wspierające chorwacki i macedoński separatyzm w ramach zdominowanego przez Serbów Królestwa Jugosławii oraz rewizjonistyczne tendencje Węgier i Bułgarii. Po zakończeniu II wojny światowej - jak zawsze, zgodnie z wolą mocarstw - granice państw bałkańskich pozostały zasadniczo niezmienione, zaś głęboko autorytarny charakter systemów politycznych państw regionu spowodował, że nierozwiązane konflikty etniczne, spory terytorialne oraz siłą stłumione procesy państwowotwórcze i dążenia separatystyczne części narodów bałkańskich pozostały na kilkadziesiąt lat „zamrożone” i w naturalny sposób „powróciły” wraz z końcem zimnej wojny na fali odradzających się i przez dekady tłumionych nacjonalizmów [Gołembski 1982: 54-105; Judah 2000: 11-12; Malcolm 2006: 24-25; Jelavich cz. I 2005: 252-257; Jezernik 2007: XIV]. W świetle powyższego postawione przez Timothy'ego G. Asha pytanie o to, ,dlaczego amerykańscy dyplomaci muszą u progu XXI wieku borykać się z problemami pozostawionymi w spadku przez rozpadające się pod koniec zeszłego stulecia imperium ottomańskie?", pozostaje w dużym stopniu uprawnione i posiada de facto charakter retoryczny [Ash 1999: 12].

Scenariusz ten dotyczył z pewnością federacyjnej i wielonarodowej Jugosławii (1945-1991). W drugiej połowie lat 80. XX w., wraz z postępującym słabnięciem poparcia społecznego dla idei wspólnego państwa oraz jego podstaw ideologicznych, w wewnątrzjugosłowiańskim dyskursie politycznym i przestrzeni publicznej ponownie pojawiła się oficjalnie zapomniana w czasach komunizmu „kwestia narodowa”. W efekcie uaktywniły się „spóźnione” i w sensie koncepcyjno-ideowym sięgające jeszcze XIX-wiecznej myśli politycznej nacjonalizmy, wróciły wspomnienia o historycznych bitwach, zwycięstwach i klęskach, narodowym poświęceniu, krzywdach i niesprawiedliwości doznanej ze strony innych narodów, odżyły mity narodowe oraz aktywnie podsycane przez republikańskie media wzajemne uprzedzenia, pretensje, obawy i stereotypy, doszło do reinterpretacji niepodważalnych ,prawd” historycznych, rehabilitacji potępianych w czasach komunizmu postaci historycznych, pojawiły się także wzajemne oskarżenia o dyskryminację mniejszości, radykalny nacjonalizm oraz działania zmierzające do zmiany dotychczasowego modelu ustrojowego federalnej Jugosławii [Silber, Little 1997: 72; Anzulovic 1999: 176-177; Todorova 2000: 161; Schwartz 2000: 101; Sell 2002: 78; Libal 2002: 1-4; Koseski 2002: 9899; Dedić 2003: 25-81; LeBor 2003: 145-146; Kollander 2004: 9; Batt 2005: 16-17; 
Banac 2006: 33-40; Žarkov 2007: 5-7; Judah 2009: 149; Dyras 2009: 33-37; Muś 2013: 63-66]. Na wagę rozbudzonych resentymentów historycznych w eskalacji konfliktów na obszarze byłej SFRJ wskazała Slavenka Drakulić, która pisała: „Moje pokolenie dorastało w Europie, wierząc, że po drugiej wojnie światowej wojna tego rodzaju nie może się nigdy powtórzyć. [...] Ale pewnego dnia przekonaliśmy się, że do rozpoczęcia wojny wcale nie jest potrzebny zewnętrzny wróg. Stało się jasne, że wróg może żyć wśród nas. Fatalne okazało się grzebanie w przeszłości. [...] Inaczej mówiąc, istniała udokumentowana historia rozlewu krwi w naszym kraju i łatwo było nią manipulować, aby skłócić jednych z drugimi” [Drakulić 2006: 7-8].

Ów swoisty ,powrót historii” wzmacniał przekonanie o historycznych i wyłącznych prawach narodów Jugosławii do określonych terytoriów oraz generował wykluczające się tendencje odśrodkowe (zwłaszcza w Słowenii, Chorwacji i Kosowie) i centralistyczne (w Serbii). Pokazał on również, że integrująca idea jugosłowiańska nie osłabiła silnej identyfikacji narodowej obywateli Jugosławii oraz nie doprowadziła do wygaszenia starych (tj. sięgających początku XX w.) międzyetnicznych konfliktów i antagonizmów, które zostały dodatkowo pogłębione wskutek bratobójczych walk narodów Jugosławii w latach II wojny światowej. Wspólny byt państwowy nie doprowadził wreszcie do odrzucenia oficjalnie ,zakazanych" w dekadach komunizmu postaw nacjonalistycznych, separatystycznych i niepodległościowych ${ }^{13}$. W efekcie na początku lat 90 . XX w. „wyzwolone” spod ograniczeń jugosłowiańskiego komunizmu narody SFRJ opowiedziały się za modelem własnego państwa narodowego, zaś tradycyjnie już sprzeczne cele polityczne oraz brak możliwości wypracowania w tym zakresie rozwiązania kompromisowego spowodowały, iż ponownie, jak wiele razy wcześniej, chwyciły one za broń, dążąc do urzeczywistnienia historycznych marzeń o własnej państwowości oraz dokończenia, czy też definitywnego rozstrzygnięcia, sporów terytorialnych, sięgających mniej lub bardziej odległej przeszłości, tocząc ze sobą te same wojny, które w XIX i XX w. stały się politycznym wyborem i doświadczeniem poprzednich generacji

${ }^{13}$ Istnieje wiele powodów, by stwierdzić, że idea „braterstwa i jedności” narodów komunistycznej Jugosławii stanowiła w dużym stopniu element oficjalnej, państwowej propagandy i nie odpowiadała rzeczywistości stosunków międzyetnicznych w powojennej federacji, które od samego początku były daleko bardziej skomplikowane. Na powyższą okoliczność wskazał T. Judah, który podkreślił, że dla części mieszkańców Jugosławii wojna bynajmniej nie skończyła się w 1945 r. i stwierdził, że „w wielu przypadkach pamięć o tym, co się naprawdę stało, przetrwała czasy komunizmu”. Podobnie argumentuje Fatos T. Lubonja, który pisał: „Często mówi się - w uproszczeniu - że 50 lat komunizmu było jak sen, który zamroził pamięć narodów; po obudzeniu się zaś odnalazły się one w stanie sprzed komunizmu. Nie jest to ścisłe. 50 lat komunizmu w Jugosławii ery Tity pokazało wprawdzie, że można żyć bez etnicznej nienawiści. Ale to tylko część tej historii. Pozostała bowiem część dowodzi, że komunistyczna ideologia wspierała się na potężnym filarze nacjonalizmu [np. przez przyjęcie podziału administracyjnego państwa, opartego na wyodrębnieniu narodowych republik i prowincji autonomicznych, rządzonych przez dominującą na danym terytorium grupę etniczną i reprezentowanych na szczeblu organów centralnych federacji -K.P.]. Komunizm nie pozwalał na rozwój społeczeństwa obywatelskiego, dawał natomiast nowe, właśnie na nacjonalizmie oparte narzędzia walki o władzę (która na Bałkanach oznacza manipulację bezosobową masą)" [Pavlowitch 1999: 169; Judah 2009: 132-133; Lubonja 1999: 15]. 
[Pavlowitch 1999: 163-170; Mazower 2000: 116-151; LeBor 2003: 141-144; Kollander 2004: 5-9; Banac 2006: 30-33; Drakulić 2006: 152; Judah 2009: 104-133; Paruch, Chmura 2012: 46].

Ten fenomen mentalnego i rzeczywistego powrotu na pole bitwy, toczonej w ramach niedokończonej, ale - w interpretacji stron - za wszech miar „sprawiedliwej wojny", odzwierciedla wypowiedź Ivana Čolovicia, który badając etnomity polityczne i kulturowe podłoże konfliktów zbrojnych na obszarze byłej Jugosławii w latach 90. XX w., wskazał na „zlewanie” się wydarzeń aktualnych i minionych oraz stwierdził, że „dystans między dawniej i teraz, między przeszłymi i obecnymi wydarzeniami niekiedy skraca się tak bardzo, że zaczynają się one pokrywać. Dwa toki baśni - jeden, w którym mowa jest o wydarzeniach współczesnych, i drugi, przywołujący podobne do nich wydarzenia z przeszłości - zlewają się w jeden, przemieniają w baśń o jakimś wydarzeniu poza czasem, nazywanym na przykład »odwieczną bitwą«, a jej głównym aktorem jest Naród [...]. W konsekwencji zniknęła różnica między nami dawniej i nami dzisiaj, między przodkami i potomnymi”, którzy tak jak ich sławni historyczni poprzednicy zostają zmuszeni do wyruszenia na wojnę w obronie ponownie zagrożonej ojczyzny [Čolović 2007: 56-58] ${ }^{14}$. Fenomen „powracającej przeszłości”, łączącej historię z teraźniejszością oraz narastające od połowy lat 80 . XX w. nastroje nacjonalistyczne i rewizjonistyczne odzwierciedla także wypowiedź Dubravki Žarkov, która wskazała, że w ówczesnej Jugosławii „W niemal postmodernistyczny sposób historia przestała być linearna i postępowa - przeszłość nie była już przeszłością, przyszłość przyszłością, wszystko działo się tu i teraz, oraz na łamach prasy" [Žarkov 2007: 3-41]. Podobnie argumentują Waldemar Paruch i Joanna Chmura, stwierdzając, że ,elity polityczne ukształtowane w państwach powstałych w warunkach jugosłowiańskich wojen sukcesyjnych oraz po definitywnym upadku struktur federacyjnych na Bałkanach zaczęły realizować politykę zdeterminowaną przez historię. Podstawowa różnica między polityką historyczną a polityką zdeterminowaną przez historię leży w sferze wolicjonalnej. W pierwszym przypadku w decydowaniu politycznym korzysta się obficie z wiedzy historycznej, podczas gdy w drugim polityka jest traktowana jako składnik procesów historycznych" [Paruch, Chmura 2012: 44].

Opinie te prowadzą do wniosku, że na początku lat 90. XX w. w świadomości narodów byłej Jugosławii doszło do swoistej projekcji, w ramach której „żyjące historią" (tj. silne tożsamościowo, świadome własnych dziejów i doznanej „,historycznej” niesprawiedliwości) narody bałkańskie zaczęły niemal dosłownie „żyć w historii”, przeżywając lub odtwarzając wydarzenia z mniej lub bardziej odległej przeszłości - w tym historii wzajemnych pretensji, konfliktów i konfrontacji - w nowym kontekście politycznym. Na ów trudny do precyzyjnego zdefiniowania stan świadomości

\footnotetext{
${ }^{14}$ Rozważania te dotyczą wprawdzie bezpośrednio narodu serbskiego, ale w istocie w mniejszym lub większym stopniu odzwierciedlają one mentalność i świadomość narodową pozostałych narodów byłej Jugosławii.
} 
zbiorowej stron konfliktów zbrojnych na obszarze byłej Jugosławii zwrócił uwagę T. Judah, który pisząc o niejednokrotnie dramatycznych losach narodu serbskiego, zauważył, że w oczach bośniackich Serbów ostrzeliwujących oblężone Sarajewo (1992-1995) ich muzułmańscy przyjaciele, sąsiedzi, a nawet krewni „stawali” się dawnymi, znienawidzonymi tureckimi wezyrami i paszami, którzy przez wieki sprawowali władzę w Bośni i ciemiężyli prawosławnych Serbów [Judah 2009: XII]. Z kolei S. Drakulić, pisząc o osobie Biljany Plavšić, wiceprezydent Republiki Serbskiej w Bośni i Hercegowinie, sądzonej przez Międzynarodowy Trybunał Karny ds. Zbrodni w byłej Jugosławii, stwierdziła: „Na pytanie, które sama sobie zadała - jak to możliwe, że Serbowie popełniali zbrodnie wojenne - jej odpowiedź brzmiała: zaślepiający strach, z którego zrodziła się obsesyjna determinacja, aby nigdy już nie stać się ofiarami, tak jak miało to miejsce w czasie wojny domowej, która rozpętała się między Serbami a Chorwatami w czasie drugiej wojny światowej. »W tej obsesji, aby nigdy więcej nie stać się ofiarami, pozwoliliśmy sobie stać się prześladowcami« - przyznała" [Drakulić 2006: 205]. W efekcie uprawnione pozostaje stwierdzenie, że tkwiące w pamięci zbiorowej narodów byłej Jugosławii wspomnienie doznanych klęsk, wzajemnych pretensji, konfliktów i okresów bezpośredniej, militarnej konfrontacji, sięgające okresu średniowiecza, panowania osmańskiego na Bałkanach, wojen bałkańskich z początku XX w. lub wydarzeń I i II wojny światowej, w istotny sposób przyczyniło się do mobilizacji społecznej oraz eskalacji działań zbrojnych na obszarze byłej SFRJ. Historia „powróciła”.

\section{NATURA HORRET VACUUM: RYWALIZACJA GEOPOLITYCZNA MOCARSTW EUROPEJSKICH}

W XVI i XVII w. będące u szczytu swej potęgi imperium tureckie było ważnym politycznym graczem w stosunkach międzynarodowych, a kolejne sukcesy militarne Osmanów niosły ze sobą bezpośrednie i realne zagrożenie dla państw Europy Środkowej i Wschodniej. W tym okresie głównym rywalem Turcji i przeszkodą dla dalszych podbojów Wysokiej Porty w Europie była monarchia Habsburgów oraz rosnąca w siłę Rosja, która dążyła do ekspansji terytorialnej w kierunku Morza Kaspijskiego. Z kolei naturalnym politycznym i militarnym sojusznikiem politycznym Turcji pozostawała rywalizująca z Habsburgami Francja oraz Rzeczpospolita Obojga Narodów, z którą Wysoka Porta toczyła wprawdzie wojny, ale jednocześnie widziała w Polsce naturalną przeciwwagę dla mocarstwowych aspiracji Moskwy ${ }^{15}$. Odnosząc się do realiów politycznych XVI-wiecznej Europy, Stephen O’Shea stwierdził, że

${ }^{15}$ Jak stwierdził M. Jačov, „przykładem zainteresowania Wysokiej Porty sprawami polskimi jest wmieszanie się Murada III w rozwiązanie kryzysu politycznego w Rzeczypospolitej po ucieczce Henryka Walezego. Sułtan nie wahał się ostrzec cesarza Maksymiliana II, aby ten nie mieszał się w wewnętrzne sprawy Rzeczypospolitej. Wykluczywszy kandydaturę Iwana Groźnego, Wysoka Porta powiadomiła ambasadora polskiego Andrzeja Tarnowskiego, że jedynym kandydatem godnym tronu polskiego jest książę 
„każdy realista postrzegał imperium osmańskie jako kolejną potęgę nieróżniącą się niczym od innych, w tym i europejskich mocarstw. Tym samym zaczęto zwracać uwagę na polityczne kontakty z Osmanami. Czy chodziło akurat o sojusz, neutralność czy otwartą wojnę, zależało od czynników politycznych, które nie miały nic wspólnego z religią" [O’Shea 2009: 398].

Bitwa pod Wiedniem (1683) okazała się kulminacyjnym punktem potęgi i ekspansji terytorialnej Turcji na kontynencie europejskim. Postępujący od początku XVIII w. proces powolnego słabnięcia państwa Osmanów był warunkowany wieloma czynnikami wewnętrznymi i międzynarodowymi, które obejmowały m.in. wewnętrzne walki o władzę, stagnację ekonomiczną, rozległość terytorium, wielonarodowy i wielokulturowy charakter państwa, rebelie antytureckie i powstania niepodległościowe narodów imperium, wreszcie powtarzające się konflikty zbrojne z Austrią i Rosją [O'Shea 2009: 247; Jezernik 2007: 34-35; Millar 2011: 87].

Rozpad imperium osmańskiego, które po okresie świetności zmagało się z procesem powolnego słabnięcia i dezintegracji, pozostawał tłem rywalizacji geopolitycznej tradycyjnych mocarstw europejskich, tj. Austrii (od 1867 r. Austro-Węgier), Rosji, Wielkiej Brytanii, Francji i Niemiec, które dążyły do realizacji własnych, partykularnych celów, nierzadko kosztem interesów narodów bałkańskich. Postępująca wewnętrzna słabość Turcji, która w XIX w. była określana mianem „chorego człowieka Europy", naruszała równowagę geopolityczną na kontynencie europejskim, a nieuchronność dalszego rozkładu państwa powodowała pytania na temat tego, jak będzie wyglądała polityczna mapa Bałkanów w sytuacji całkowitego rozpadu imperium. W drugiej połowie XIX w. i na początku XX w. powyższy problem (tzw. kwestia wschodnia) stanowił jedno z podstawowych zagadnień polityki europejskiej oraz istotny przedmiot debat, sporów i rozwiązań politycznych, wypracowywanych w ramach istniejącego wówczas koncertu mocarstw, w którym uczestniczyły ówczesne potęgi europejskie. Państwa te w różny sposób odnosiły się do problemu dezintegracji imperium tureckiego. Jeśli zatem Austro-Węgry i Rosja dążyły do dalszego osłabienia Turcji, Francja i Wielka Brytania, obawiając się nadmiernego wzmocnienia Austro-Węgier i Rosji kosztem słabnącego państwa osmańskiego, starały się ograniczyć skutki i tempo jego rozpadu i dążyły do zachowania regionalnego status quo, a kiedy okazało się to niemożliwe, opowiedziały się za powstawaniem na obszarze Bałkanów bloku państw narodowych, które miały stanowić naturalną przeciwwagę dla ekspansji terytorialnej Wiednia i Moskwy. Historia pokazała jednak, że wskutek rozbieżnych interesów oraz nasilającej się rywalizacji mocarstw europejskich w skali ogólnoeuropejskiej i globalnej wpisany w logikę koncertu mocarstw mechanizm stabilizacji bezpieczeństwa międzynarodowego w Europie na dłuższą metę okazał się nieskuteczny i ostatecznie doprowadził do wybuchu I wojny światowej, której katalizatorem stały się napięcia i konflikty istniejące w regionie

Siedmiogrodu, wasal sułtana - Stefan Batory. Nie jest chyba przypadkiem, że wkrótce po ukoronowaniu Batory rozpoczął wojnę przeciwko Moskwie" [Jačov 2005: 190-191; O’Shea 2009: 293]. 
Bałkanów [Gołembski 1982: 54-93; Tanty 2003: 5-6; Jelavich cz. I 2005: 243-249; Jezernik 2007: XI].

Jak pisał B. Jezernik, ,pierwsza wojna światowa w latach 1914-1918 położyła w końcu kres Imperium Osmańskiemu i zamknęła ostatecznie Kwestię Wschodnią, ale problem utrzymania stabilności w regionie zdominowanym niegdyś przez Turcję pozostał, podobnie jak sprzeczne interesy spoglądających na Półwysep Bałkański mocarstw europejskich" [Jezernik 2007: XII]. W okresie międzywojennym skłócone i podzielone państwa bałkańskie ponownie były poddawane zatem naciskom i presji politycznej ze strony mocarstw europejskich, które w ramach tradycyjnej rywalizacji wspierały lub starały się torpedować polityczną integrację państw Europy Środkowej i Południowo-Wschodniej (przykładem pozostaje wskazywana już ekspansjonistyczna i par excellence rewizjonistyczna polityka faszystowskich Niemiec i Włoch, mająca na celu osłabienie i rozbicie wspieranych przez Francję struktur wielostronnych w postaci Małej Ententy i Ententy Bałkańskiej, czy też zablokowanie przez ZSRR planów komunistycznych przywódców Jugosławii, dążących w połowie lat 40. XX w. do utworzenia silnej struktury integracyjnej w postaci tzw. federacji bałkańskiej). Z kolei w dekadach zimnej wojny integracja Europy Południowo-Wschodniej była ograniczona istnieniem w regionie państw o odmiennych systemach politycznych i ekonomicznych, należących do wrogich obozów wojskowych [Wasilewski, Felczak 1985: 454-465; Crampton 2002: 113-155; Walkiewicz 2000: 161-200]. Geopolityka zimnej wojny spowodowała zatem, że - jak stwierdziła Barbara Jelavich - „tak jak w przeszłości, pięć państw bałkańskich wykazało się niezdolnością do połączenia swych sił, by oprzeć się dominacji wielkich mocarstw. Każde poszło własną drogą i szukało odmiennego sposobu dostosowania się do sytuacji międzynarodowej, zdominowanej przez dwa wojskowe supermocarstwa: ZSRR i Stany Zjednoczone" [Jelavich cz. II 2005: 348].

Tradycyjna geopolityczna perspektywa mocarstw dała o sobie znać również na początku lat 90. XX w., kiedy to wśród głównych aktorów międzynarodowych w tym także w gronie państw Zachodu - dochodziło do polemik i sporów dotyczących właściwej strategii działania społeczności międzynarodowej wobec problemu Jugosławii. W efekcie mocarstwa europejskie prowadziły politykę niemal dziewiętnastowieczną, w ramach której Niemcy i Austria konsekwentnie popierały secesjonistyczne dążenia Słoweńców i Chorwatów, zaś Wielka Brytania, Francja i Rosja wspierały politycznie Serbię i początkowo opowiadały się za kontynuacją federacji jugosłowiańskiej [Chernishev 1995: 243-244; Anzulovic 1999: 177; Tochman 2002: 6]. Na powyższą sytuację wyraźnie zwrócił uwagę w 1992 r. Josef Joffe, który wskazywał na istnienie ,„»nowego ładu europejskiego«, który podejrzanie przypomina stary" oraz stwierdził, że sposób, w jaki państwa ówczesnej Wspólnoty Europejskiej podchodziły do problemu rozpadu federacji jugosłowiańskiej, „wyglądał [...] jak powtórka I wojny światowej: Francja i Wielka Brytania [obawiające się, że zjednoczenie Niemiec doprowadzi do odbudowy tradycyjnej niemieckiej strefy wpływów w Europie Środkowej, nadmiernego wzmocnienia RFN i zaburzenia powojennej 
równowagi sił na Starym Kontynencie - K.P.] po cichu zwarły szyki, popierając swego starego sojusznika - Serbię, Niemcy zaś wzięły stronę Chorwacji i Słowenii, niegdyś należących do Habsburgów. [...] Wspólna polityka bezpieczeństwa? Tu również Jugosławia, niczym światło błyskawicy, obnażyła miałkość europejskich ambicji. [...] Niemcy zachowały odrębną pozycję, zasłaniając się - dyskusyjną zresztą - interpretacją konstytucji, zabraniającą działań wojskowych innych niż samoobrona. A Brytyjczycy, Francuzi, Włosi? Ci są przynajmniej gotowi wysłać symboliczne siły na odsiecz Sarajewu. Ale w tym momencie kończy się harmonia. Francuzi chcą, by dowodziła Unia Zachodnioeuropejska - »zbrojne ramię« Wspólnoty. Brytyjczycy woleliby maszerować pod flagą ONZ. Londyn chętnie utrzymałby przy życiu NATO. Paryż, jak zwykle, wyniosły, nie zniesie jakiegokolwiek porozumienia, które by sprzyjało »hegemonii« Stanów Zjednoczonych. Morał całej historii jest smutny: Europa ma wszelkie dane, by zostać supermocarstwem, z wyjątkiem dwóch: wspólnego interesu i wspólnej woli. I nie powinno to nikogo zaskakiwać" [Joffe 1992: 6; Kollander 2004: 19].

\section{DEUS EX MACHINA: POLITYKA INTERWENCJONIZMU I ZEWNĘTRZNY PATERNALIZM}

Nieuregulowana kwestia wschodnia powodowała, że działające w imię swoich partykularnych interesów dynastycznych i geopolitycznych mocarstwa europejskie w XIX i w pierwszej połowie XX w. podejmowały z pozycji siły wiele interwencji politycznych i militarnych, skutecznie wpływając na rozwój stosunków międzynarodowych w regionie Bałkanów. Interwencje mocarstw zewnętrznych były (i pozostają) w istocie charakterystycznym elementem stosunków w regionie bałkańskim. Wyraźnie podkreśliła ten fakt B. Jelavich, która odnosząc się do historii regionu, stwierdziła, że „żyjąc w regionie międzynarodowych napięć, mieszkańcy Bałkanów poddawani byli stałym naciskom z zagranicy”, a „kwesta narodowa i interwencje z zewnątrz pozostały największymi problemami Bałkanów" [Jelavich cz. I 2005: 11; Jelavich cz. II 2005: 257].

Na podstawie zasady divide et impera mocarstwa europejskie wielokrotnie narzucały narodom i państwom bałkańskim określone rozwiązania polityczne i terytorialne, w sposób arbitralny decydując o samym istnieniu i granicach nowo powstałych państw, systemie władzy, osobie władcy, a pośrednio (tj. przez powiązania dynastyczne i sojusze polityczno-wojskowe) również prowadzonej przez państwa bałkańskie polityce zagranicznej, skutecznie antagonizując i angażując narody i państwa Półwyspu w europejską i światową rywalizację mocarstw. Wyraźnie zaakcentował ten fakt Franciszek Gołembski, który stwierdził, że proces formowania się niepodległych państw bałkańskich w XIX w. i na początku XX w. w daleko idącym stopniu był zależny od woli mocarstw europejskich, które wywierały istotny wpływ na rozwój wydarzeń w regonie i decydując o kształcie mapy politycznej Bałkanów, 
w pierwszym rzędzie dążyły do zabezpieczenia własnych interesów dynastycznych i państwowych [Gołembski 1982: 54-105; Garlicka 1983: 364-412; Mazower 2000: 93-94; Pavlowitch 2000: 141-148].

Politykę zewnętrznego politycznego i militarnego interwencjonizmu na Bałkanach w XIX w. i pierwszej połowie XX w. ułatwiała obiektywna polityczna, gospodarcza i militarna słabość narodów i państw Europy Południowo-Wschodniej. Sytuacja ta powodowała, że mieszkańcy Bałkanów nie byli w stanie sprzeciwić się zewnętrznej presji i ingerencji, a dodatkowo - świadomi swej słabości - byli zmuszeni do zabiegania o polityczne i wojskowe wsparcie mocarstw oraz akceptacji ich woli politycznej, czasem wbrew własnym interesom i aspiracjom narodowym. W efekcie mocarstwa zewnętrzne skutecznie sterowały niepodległościowymi i terytorialnymi aspiracjami narodów Europy Południowo-Wschodniej oraz wykorzystywały liczne regionalne konflikty wewnątrzpaństwowe i międzynarodowe na rzecz realizacji własnych interesów geopolitycznych. Działania te skutkowały wybuchem w regionie kolejnych konfliktów zbrojnych oraz celowym lub de facto naturalnym antagonizowaniem narodów i państw bałkańskich, które włączały się w rywalizację mocarstw po przeciwnych stronach frontu, widząc w tym jedyną możliwość zabezpieczenia własnych interesów narodowych oraz sposób na urzeczywistnienie określonych aspiracji terytorialnych (zwykle kosztem najbliższego sąsiada) [Gołembski 1982: 59-105]. Powyższą sytuację trafnie podsumował B. Jezernik, który w kontekście wojen na Bałkanach w XIX i na początku XX w. stwierdził: ,przyczyny i skutki były zawsze podobne. Każdy z krajów bałkańskich miał swe własne cele a potęgi europejskie dążyły do kontrolowania biegu wydarzeń i zaspokajania swoich ambicji” [Jezernik 2007: XI-XII]. I jeśli spory terytorialne i konflikty interesów między narodami i państwami bałkańskimi, ,wyłaniającymi” się na Półwyspie Bałkańskim wraz z postępującym słabnięciem wielonarodowej Turcji, były zjawiskiem w pełni zrozumiałym, ,sprzeczne interesy mocarstw europejskich sprawiły, że stały się one jeszcze bardziej gorzkie i krwawe" [Jezernik 2007: XIV].

Podsumowując, należy stwierdzić, że w XIX i XX w. mocarstwa zewnętrzne wielokrotnie, bezpośrednio i skutecznie decydowały o przebiegu i kształcie procesu rozpadu państwa osmańskiego oraz mapie politycznej Bałkanów (w tym o granicach państwowych na obszarze Europy Południowo-Wschodniej po zakończeniu I i II wojny światowej), zaś narody i państwa bałkańskie były zmuszone do akceptowania arbitralnie narzuconych im rozwiązań terytorialnych i ustrojowych, które posiadały wprawdzie oficjalną akceptację mocarstw, ale nierzadko były otwarcie sprzeczne z oczekiwaniami i aspiracjami narodów bałkańskich oraz w oczywisty sposób ignorowały istniejące i ukształtowane na przestrzeni wieków ,granice” etniczne [Gołembski 1982: 60-61; Mazower 2000: 94].

Podobna sytuacja miała również miejsce w latach 90. XX w., kiedy to w sytuacji rozpadu SFRJ społeczność międzynarodowa, powołując się na zasadę uti possidetis iuris, opowiedziała się za uznaniem granic republik SFRJ w charakterze nowych granic państwowych, co de facto i de iure przesądziło o kształcie granic państw 
sukcesyjnych na obszarze byłej Jugosławii oraz ponownie wymusiło na niektórych narodach byłej federacji uznanie „niechcianych” lub niesatysfakcjonujących rozstrzygnięć terytorialnych ${ }^{16}$. Wyraźnie podkreślił ten fakt Marek Waldenberg, który stwierdził, że uznanie secesji Słowenii i Chorwacji przez państwa zachodnie miało charakter uznania przedwczesnego i faktycznie przesądziło o losie federacji. Stwierdził również, że w procesie rozpadu Jugosławii kluczowe znaczenie odegrała polityka tradycyjnie wrogich Serbii i idei jugosłowiańskiej Niemiec i Austrii, które podsycały i wspierały tendencje secesjonistyczne w Słowenii i Chorwacji [Waldenberg 2003: 86-103]. Jak zatem stwierdził M. Waldenberg, „na los Jugosławii największy wpływ wywierały w latach 1990-1991 główne państwa WE, Republika Federalna Niemiec, Francja i Wielka Brytania. Związek Radziecki zajęty był sobą. USA nie chciały jeszcze odgrywać pierwszoplanowej roli. [...] Tragedie, które [...] przeżywają narody Jugosławii, stanowią konsekwencję nie tylko tego, że państwo to zostało rozbite. Ogromne rezultaty tych dramatów są rezultatem sposobu, w jaki nastąpił jego kres, forsowanego przez RFN od lata 1991 r. pośpiesznego uznania secesji. [...] To, że na rządzie RFN ciąży szczególnie wielka odpowiedzialność za nieszczęścia narodów Jugosławii, nie ulega wątpliwości” [Waldenberg 2003: 86-91].

Należy podkreślić, że część narodów SFRJ otwarcie odrzuciła stanowisko społeczności międzynarodowej, zmuszające je do akceptacji terytorialnego status quo, będącego administracyjnym dziedzictwem federacyjnej Jugosławii, które w niektórych przypadkach wyraźnie nie odzwierciedlało istniejących i historycznych już wówczas „granic” etnicznych ${ }^{17}$. Powołując się na prawo do samostanowienia,

${ }^{16}$ Wyrazem powyższego stanowiska społeczności międzynarodowej stało się inter alia przyjęcie do ONZ 22 maja 1992 r. Słowenii, Chorwacji oraz Bośni i Hercegowiny, odrzucenie możliwości kontynuacji członkostwa SFRJ w ONZ przez nowo powstałą Federacyjną Republikę Jugosławii (obejmującą terytorium Serbii i Czarnogóry) oraz stanowisko Komisji Arbitrażowej Konferencji w sprawie Jugosławii, utworzonej przez Wspólnotę Europejską w celu rozpatrzenia prawnych aspektów wydarzeń na obszarze byłej SFRJ, która jednoznacznie stwierdzała, że SFRJ uległa rozpadowi, a istniejące wcześniej granice republik jugosłowiańskich powinny zostać uznane za nowe granice państwowe i mogą one zostać zmienione wyłącznie przy zastosowaniu środków pokojowych, na podstawie stosownego porozumienia państw sukcesyjnych. W konsekwencji państwa WE wyraziły gotowość uznania wszystkich republik byłej SFRJ w dotychczasowych granicach terytorialnych [Zimmermann, Stahn 2001: 425-440; Wierzbicki 2008: 150-154; Shaw 2006: 291-292; Jackson 2011: 125-142].

${ }_{17}$ Warto przytoczyć w tym miejscu opinię Predraga Simicia, który stwierdził, że najbardziej krwawe konflikty zbrojne na terytorium byłej Jugosławii (1991-1999) miały miejsce dokładnie na obszarach dawnych granic między imperiami, takich jak Bośnia i Hercegowina, czy też Krajina w dzisiejszej Chorwacji, gdzie od XVII w. imperium Habsburgów osiedlało serbskich uchodźców z państwa osmańskiego w celu zabezpieczenia granicy przed zagrożeniem militarnym ze strony Turcji. Na początku lat 90 . XX w. istniały zatem historyczne i zwarte pod względem terytorialnym skupiska ludności serbskiej na terytorium Republiki Chorwacji, gdzie mniejszość serbska stanowiła 12\% ludności, oraz Republiki Bośni i Hercegowiny, gdzie Serbowie tworzyli drugą pod względem wielkości grupę narodowościową, obejmującą 31,3\% populacji. Kiedy Chorwaci i bośniaccy Muzułmanie zdecydowali o wystąpieniu z Jugosławii, dotychczasowe granice republikańskie pozwalały im na „zabranie” terytoriów, których nie mogliby zyskać, gdyby rozpad SFRJ nastąpił wzdłuż ,granic” etnicznych, a nie republikańskich. Sprzeciw ludności serbskiej, aktywnie wspieranej przez władze Republiki Serbii, doprowadził ostatecznie do wybuchu działań zbrojnych na terytorium Chorwacji (1991) oraz Bośni i Hercegowiny (1992). W przypadku Chorwacji konflikt ten został rozstrzy- 
narody te bezskutecznie dążyły do jednostronnego i siłowego wyznaczenia nowych granic państwowych, pozwalających na integrację terytoriów zamieszkiwanych przez daną grupę etniczną w ramach jednego organizmu państwowego (Serbowie i Chorwaci) lub uzyskanie niepodległości (kosowscy Albańczycy) [Silber, Little 1997: 193-194; Libal 2002: 10; Batt 2005: 12-18; Banac 2006: 42; Popovic 2006: 49; Judah 2009: 314-315]. Złożoność powyższej sytuacji odzwierciedla opinia Louisa Sella, który stwierdził, że prawdopodobnie największym koncepcyjnym błędem społeczności międzynarodowej było „niepowodzenie, aby w takim samym stopniu odnieść się do żądań [...] wszystkich narodów, które zamieszkiwały byłą Jugosławię. Poprzez kurczowe trzymanie się stanowiska, że wewnętrzne granice republik, które tworzyły Jugosławię, muszą pozostać utrzymane jako zewnętrzne granice nowych państw, które wyłoniły się z rozpadu Jugosławii, społeczność międzynarodowa odmówiła Serbom i Albańczykom - a więc obu narodom Jugosławii, których granice etniczne w największym stopniu nie odpowiadały istniejącym granicom politycznym - prawa do posiadania niepodległego państwa narodowego, które zostało przyznane Słoweńcom, Chorwatom, Macedończykom i Bośniakom" [Sell 2002: 6].

\section{ZAKOŃCZENIE}

Podsumowując, należy stwierdzić, że w analizie daleko skomplikowanego i pozostającego przedmiotem niesłabnących sporów procesu dezintegracji byłej Jugosławii konieczne wydaje się szersze uwzględnienie również uwarunkowań stricte historycznych. Istnieje bowiem wiele powodów, by uznać, że w sposób pośredni przyczyniły się one do rozpadu SFRJ oraz krwawych wojen sukcesyjnych [Mazower 2000: 151; Čolović 2007: 13-14]. Uczciwe spojrzenie wstecz w historię narodów i państw bałkańskich tworzy zatem pełną i właściwą perspektywę badawczą dla analizy przyczyn, przebiegu i skutków procesu dezintegracji byłej Jugosławii, wolną od nadmiernych i krzywdzących uproszczeń, koniunkturalizmu (historię przedstawia się wszak zwykle z perspektywy zwycięzców), dominujących intelektualnych mód, manipulacji prawdą historyczną na użytek bieżącej polityki wewnętrznej lub międzynarodowej, czy też otwartej, wrogiej propagandy. Co więcej, sięgnięcie do przeszłości z pewnością pozwala na lepsze zrozumienie obecnej dynamiki stosunków międzynarodowych i wewnątrzpaństwowych na obszarze pojugosłowiańskim. Jak bowiem pisał historyk i filozof Ernst Troeltsch (1865-1923), „państwo, prawo, moralność, religia, sztuka, roztapiają się w rzece stawania się dziejów i są dla nas zrozumiałe tylko jako części składowe przemian historycznych" [Szacki cz. II 1981: 473].

gnięty na drodze militarnej, kiedy to wskutek zwycięskiej ofensywy armii chorwackiej (1995) doszło do upadku samozwańczej Serbskiej Republiki Krajiny i fali setek tysięcy serbskich uchodźców (de facto czystki etnicznej), która w praktyce zakończyła liczącą kilkaset lat obecność wspólnoty serbskiej na terytorium dzisiejszej Chorwacji [Cappelli 1997: 104; Simic 2001: 20-21; Hamourtziadou 2002: 149-155; LeBor 2003: 229; Batt 2005: 15-16]. 
Rozważania zawarte w niniejszej publikacji skłaniają do wniosku, że spory terytorialne, problemy narodowościowe i konflikty etniczne, które w latach 90. XX w. doprowadziły do dezintegracji SFRJ, stanowią inter alia dziedzictwo skomplikowanej historii politycznej regionu, wynikającej w pierwszym rzędzie z wielowiekowej okupacji Bałkanów przez osmańską Turcję oraz politycznej obecności i dominacji w regionie rywalizujących mocarstw europejskich. Wyraźnie zaakcentował ten fakt T. Judah, wskazując, że historia narodów bałkańskich w dużym stopniu tłumaczy ich współczesne działania, postawy i świadomość narodową. Jakkolwiek zaznaczył on, że dziedzictwo historyczne nie usprawiedliwia w żaden sposób brutalności jugosłowiańskich wojen sukcesyjnych, wskazał równocześnie, że dramatyczny przebieg rozpadu Jugosławii po zakończeniu zimnej wojny stanowił po części skutek negatywnych doświadczeń historycznych, konkludował także, że gdyby historia narodów byłej Jugosławii była inna, obecne generacje nie dałyby się tak łatwo sprowokować i pchnąc do zbrojnej konfrontacji [Judah 2009: XII-XIV]. Na historyczne uwarunkowania procesu dezintegracji SFRJ zwrócił również uwagę Branimir Anzulović, który podkreślił, że współczesne problemy narodów byłej Jugosławii pozostają w bardzo dużym stopniu następstwem ich dziejów historycznych. Wyraził on również nadzieję, że uświadomienie tego faktu doprowadzi do zastanowienia i opamiętania oraz efektu katharsis, które pozwolą narodom byłej Jugosławii lepiej zrozumieć specyfikę własnego rozwoju społeczno-politycznego i bardziej krytyczne spojrzeć na najnowszą historię regionu [Anzulovic 1999: VII]. W końcu - jak stwierdził kiedyś niemiecki polityk Carlo Schmid (1896-1979) - „godność narodowa polega też na przyznawaniu się do własnej historii” [Jacobsen 2000: 52].

Skomplikowana i ,powracająca” w momentach napięć i przesileń politycznych historia regionu - a ściślej, nierozwiązane spory terytorialne i wykluczające się dążenia polityczne - w dużym stopniu tłumaczy zatem, dlaczego po zakończeniu zimnej wojny na obszarze byłej Jugosławii ponownie doszło do wybuchu konfliktów zbrojnych i aktów międzyetnicznej przemocy. Powyższy wniosek daleki jest jednak od jakiegokolwiek determinizmu historycznego czy też bliskiego historyzmowi myślenia w kategoriach praw historycznych, które w daleko uproszczonej formie prowadzą do nieuprawnionej konkluzji, że mieszkańcy Bałkanów dążą do kolejnych konfliktów zbrojnych „,z powodu” swojej historii. Wojna nigdy nie jest „historyczną koniecznością", a zależność między historią i współczesnością może być wprawdzie widoczna i wyraźna - historia jest w końcu, jak twierdził historyk Edward A. Freeman (1823-1892), przeszłą polityką, a polityka współczesną historią - ale nie posiada ona charakteru absolutnego [Ratcliffe 2011: 207]. Przeciwnie, wbrew obiegowym opiniom społeczeństwa nie tkwią w pułapce swej historii i mogą zmieniać jej bieg. Potwierdzają to słowa kanclerza Niemiec Willy’ego Brandta (1913-1992), który w 1971 r., odbierając Pokojową Nagrodę Nobla przyznaną w uznaniu za zaangażowanie w proces pojednania z państwami Europy Wschodniej i przezwyciężanie ówczesnego podziału Europy, których symbolem stało się uklęknięcie kanclerza RFN w grudniu 1970 r. przed pomnikiem Bohaterów Getta w Warszawie, stwier- 
dził: „Ufam, że zrozumiecie [...] jak wiele to dla mnie znaczy, że moje wysiłki podejmowane $» \mathrm{w}$ imieniu narodu niemieckiego « zostały docenione; że otrzymałem nagrodę po niemożliwych do zapomnienia okropnościach z przeszłości, że widzę obok siebie nazwę mojego państwa i pragnienie pokoju" [Nobelprize.org. The Offical Web Site of the Nobel Prize, http://www.nobelprize.org/nobel_prizes/peace/laureates/1971/brandt-acceptance.html; Coellen, Metzner 2011: http://www.dw.com/ p1/40-lat-pokojowej-nagrody-nobla-dla-willi-brandta/a-15474211].

Przypomnienie o roli uwarunkowań historycznych w procesie dezintegracji Jugosławii nie oznacza zatem, że wskutek ,powracającego" na przestrzeni XIX i XX w. zderzenia aspiracji politycznych i roszczeń terytorialnych narodów bałkańskich musiało dojść do rozpadu wielonarodowego państwa i krwawych wojen sukcesyjnych. Jakkolwiek w sytuacji wyraźnej intensyfikacji wewnętrznych tendencji dezintegracyjnych, będących w istocie podstawowym problemem politycznym „każdej” Jugosławii, twierdzenia o możliwości przetrwania federacji jugosłowiańskiej wydają się być dyskusyjne, pokojowy sposób „rozwodu” między narodami Jugosławii na wzór Czechosłowacji (1993) był z pewnością możliwy. Niestety, scenariusz ten został w oczywisty sposób zaprzepaszczony przez część elit republikańskich, które budowały swój kapitał polityczny na tradycyjnie silnych bałkańskich nacjonalizmach, mitach narodowych, zakorzenionych w historii wzajemnych strachach i uprzedzeniach oraz niezrealizowanych przez poprzednie pokolenia niepodległościowych aspiracjach politycznych, i doprowadziły ostatecznie do wybuchu wojen oraz dramatu narodów Jugosławii. Krwawy rozpad Jugosławii nie był zatem nieuchronny. Przeciwnie, stanowił on wynik określonych wyborów politycznych, dokonanych na początku lat 90 . XX w. przez nieodpowiedzialne, postkomunistyczne elity i zmanipulowane przez nie społeczeństwo, które w nacjonalizmie i „,ucieczce do przeszłości” widziało alternatywę dla rozpadającej się i w wielu aspektach dysfunkcjonalnej, wspólnej państwowości oraz archaicznej już wówczas ideologii jugosłowiańskiego komunizmu [Judah 2009: XII].

Należy również wyraźnie podkreślić, że w przypadku wojen bałkańskich lat 90 . XX w. subiektywna i selektywna interpretacja historii regionu i jego mieszkańców stała się istotnym środkiem walki politycznej oraz instrumentem nacjonalistycznej propagandy, dostarczającej idealnego usprawiedliwienia dla aktów przemocy wobec drugiej strony konfliktu. Mitologizacja przeszłości, selektywne uwzględnianie faktów, a nawet ich oczywista falsyfikacja, dokonywane w celu uzasadnienia i moralnego usprawiedliwienia stanowiska i działań własnej grupy etnicznej, z pewnością przyczyniły się do rozpadu Jugosławii oraz wybuchu i eskalacji konfliktów zbrojnych $^{18}$.

${ }^{18}$ Odnosząc się do argumentów historycznych, przywoływanych przez narody bałkańskie w celu uzasadnienia swych roszczeń politycznych, L. Sell - nie bez ironii - stwierdził, że „w historii Bałkanów, podobnie, jak w statystyce, możliwe jest udowodnienie niemal wszystkiego poprzez wybranie odpowiedniego punktu [tj. okresu historycznego - K.P.] do rozpoczęcia rozważań”. Podobnie wskazał T. Judah, który w kontekście konfliktu serbsko-albańskiego o terytorium Kosowa zauważył, że w celu uzasadnienia 
Rozważania poświęcone historii regionu Bałkanów uprawniają wreszcie do kontrowersyjnego skądinąd stwierdzenia, że przynajmniej część odpowiedzialności za polityczną niestabilność Europy Południowo-Wschodniej po zakończeniu zimnej wojny ponoszą również aktorzy zewnętrzni, tj. działające w imię swoich geopolitycznych interesów mocarstwa europejskie, których działania i decyzje w XIX i pierwszej połowie XX w. skutecznie i wielokrotnie uniemożliwiły „dokończenie” procesów państwowotwórczych, zgodnych z wolą i ambicjami narodów bałkańskich oraz ustanowienie w regionie granic państwowych, które w większym stopniu odpowiadałyby istniejącej strukturze etnicznej i aspiracjom terytorialnym mieszkańców Półwyspu. Co więcej, zaangażowanie społeczności międzynarodowej w wypracowanie (de facto narzucenie) rozwiązania politycznego, kończącego wojny sukcesyjne na obszarze byłej Jugosławii w latach 90. XX w. uprawnia do stwierdzenia, że ,historia lubi się powtarzać", i tak jak w przeszłości również obecnie tradycyjnie już podzielone narody i państwa bałkańskie pozostają de facto przedmiotem, a nie podmiotem stosunków międzynarodowych.

Jest także bardzo prawdopodobne, że faktyczne narzucenie oraz wymuszenie przez społeczność międzynarodową formalnej akceptacji zasady uti possidetis przez mieszkańców byłej Jugosławii przyczyniło się do kontynuacji licznych konfliktów wewnątrzpaństwowych oraz systemowej słabości części państw pojugosłowiańskich. W efekcie, w literaturze można się spotkać z głosami, że upór społeczności międzynarodowej dla zachowania terytorialnego status quo na obszarze byłej SFRJ oraz wspieranie za cenę zatrzymania działań zbrojnych rozwiązań politycznie i prawnie kontrowersyjnych (np. ostatecznego uznania niepodległości Kosowa, będącego paradoksalnie drugim w regionie państwem albańskim) lub daleko dysfunkcjonalnych (np. zachowania integralności terytorialnej Bośni i Hercegowiny, oznaczającej wymuszoną i nadzorowaną przez wspólnotę międzynarodową koegzystencję Bośniaków, Serbów i Chorwatów w ramach jednego organizmu państwowego), które ignorują istniejącą rzeczywistość społeczną, polityczną i ekonomiczną, a dodatkowo - według niektórych opinii - nie mają podstaw historycznych i szans powodzenia w dłuższym okresie wskutek instytucjonalnej słabości oraz obojętności, braku poparcia, a nawet otwartego sprzeciwu części społeczeństwa, będzie raczej prowadzić do nawarstwiania się problemów wewnątrzpaństwowych i międzynarodowych, a nie ich rozwiązania [Anzulovic 1999: 179-180; Daianu 2000: 11].

\footnotetext{
swych roszczeń terytorialnych i podejmowanych działań obie strony konfliktu wyraźnie - oraz często przesadnie - odwołują się do historii i interpretują ją w skrajnie odmienny, korzystny dla siebie sposób, zaś skala tego zjawiska powoduje, że - parafrazując znaną maksymę - historia, a ściślej jej upolityczniona i daleko jednostronna interpretacja, staje się „wojną prowadzoną za pomocą innych środków”. O tym, że wykorzystanie argumentów historycznych na użytek bieżącej polityki dotyczy także innych narodów bałkańskich, dobitnie świadczy rola, jaką instrumentalne odwoływanie się do argumentów historycznych odgrywa w konflikcie między Macedonią i Grecją, która od początku lat 90. XX w. konsekwentnie zarzuca władzom w Skopje historycznie nieuzasadnione wykorzystanie nazwy, symboliki i historii starożytnej Macedonii, będących w opinii władz w Atenach częścią greckiego dziedzictwa kulturowego [Sell 2002: 65; Tziampiris 2003: 225-252; Judah 2000: 1-4].
} 
Kończąc, warto odwołać się do jednej z najbardziej znanych myśli Georga Wilhelma Friedricha Hegla (1770-1831), który stwierdził, iż „doświadczenie i historia uczą, że ani lud ani rządy nigdy niczego się z historii nie nauczyły i nigdy nie postępowały według nauk, które należałoby z niej czerpać" [Jakubowski 2001: 171]. I choć wielki filozof opowiadał się za linearną koncepcją rozwoju cywilizacji ludzkiej i nie widział w tym niczego błędnego, uznając, że - jak wskazał Marek N. Jakubowski - „,W wiedzy przeszłych faktów (wbrew temu co sądził Tukidydes i zastępy historyków po nim) nie możemy znaleźć instrukcji dla działań przyszłych. Dzieje bowiem nie są cyklicznym powrotem", wiele uwagi poświęcił poszukiwaniu prawidłowości rozwoju dziejowego oraz kwestii ogólnego kierunku procesu historycznego [Jakubowski 2001: 171; Szacki cz. I 1981: 211-213]. Jest zatem wielce prawdopodobne, że bardziej wnikliwa lektura historii Bałkanów - lub mniejsza ignorancja dla tejże historii - ze strony światowych decydentów, którzy tak jak w przeszłości również po zakończeniu zimnej wojny w praktyce zadecydowali o politycznej mapie Bałkanów Zachodnich, pozwoliłaby na uniknięcie kolejnych „zamrożonych” konfliktów i wykluczenie możliwości ich eskalacji w mniej lub bardziej odległej przyszłości [Kissinger 2000: 294; Kaplan 2000: 344-348; Luttwak 2000: 349-355]. Historia bowiem - wbrew temu co sądzą niektórzy filozofowie - nigdy się „nie kończy” i można się spodziewać, że w momencie wystąpienia kolejnych poważnych zmian systemowych o charakterze regionalnym lub globalnym na Bałkanach dojdzie do ponownego „powrotu historii”. Biorąc pod uwagę instytucjonalną słabość niektórych państw regionu, dyskusyjne poparcie lub otwartą kontestację niektórych państwowości bałkańskich przez część własnych obywateli, nierozwiązane spory terytorialne, aktywne konflikty etniczne oraz w dalszym ciągu konieczne polityczne, militarne i ekonomiczne zaangażowanie społeczności międzynarodowej w stabilizację i rozwój regionu, ten pesymistyczny scenariusz nie może zostać definitywnie odrzucony. Tym bardziej że na Bałkanach - zwłaszcza zaś na obszarze byłej SFRJ - świadomość bycia „ofiarą" historii, poczucie doznanej klęski i niesprawiedliwości, kontestacja formalnie istniejących granic państwowych, sprzeciw wobec narzuconych przez społeczność międzynarodową rozwiązań ustrojowych, chęć rewanżu oraz opór wobec uczciwego rozliczenia się z własną i nieodległą historią wydają się być w dalszym ciągu większe i intensywniejsze niż w innych częściach Europy. Istnieje zatem wiele powodów, by twierdzić, że w świadomości części narodów bałkańskich historia jeszcze się ,nie zakończyła”, a istniejący pozimnowojenny układ stosunków międzynarodowych i wewnątrzpaństwowych w regionie Europy Południowo-Wschodniej nie jest bynajmniej „zwieńczeniem historii”. Historia zaś - jak ostrzegał inny słynny kanclerz Niemiec, Konrad Adenauer (1876-1967) - pełna jest rzeczy, których można było uniknąć [Ratcliffe 2011: 208]. 


\section{BIBLIOGRAFIA}

Andreev, S.A. 2004. The Borders in Southeast Europe - Democratic Legitimacy and Security Issues in an Enlarging European Union, „Southeast European and Black Sea Studies”, vol. 4 (3).

DOI: https://doi.org/10.1080/1468385042000281611.

Anzulovic, B. 1999. Hevenly Serbia. From Myth to Genocide, NYU Press, London.

Ash, T.G. 1999. Żal za magiczna jaskinia, „Gazeta Wyborcza” 23-24.01.

Banac, I. 2006. The politics of national homogeneity, [w:] War and Change in the Balkans. Nationalism, Conflict and Cooperation, B.K. Blitz (red.), Cambridge University Press, Cambridge.

Batt, J. 2005, The question of Serbia, Institute for Security Studies of European Union, Paris.

Blumi, I. 2006. Is Kosova a late creation of the Yugoslav state and should it be considered the cradle of the Serb nation?, [w:] The Case for Kosova. Passage to Independence, A. Di Lellio (red.), Anthem Press, London-New York.

Cappelli, V. 1997. The Bosnian Question and the Great Powers, „Mediterranean Quarterly”, vol. 8 (1).

Chernishev, A.S. 1995. Balkans and Russia, [w:] Balkans. A Mirror of the New International Order, G.G. Özdogan, K. Saybasili (red.), Eren, Istambul.

Coellen, B., Metzner, I.D. 2011. 40 lat Pokojowej Nagrody Nobla dla Willi Brandta, DW, http://www.dw.com/ pl/40-lat-pokojowej-nagrody-nobla-dla-willi-brandta/a-15474211 (dostęp: 15.07.2016).

Crampton, R.J. 2002. The Balkans Since the Second World War, Routledge, Harlow.

Čolović I. 2007, Batkany - terror kultury, Wydawnictwo Czarne, Wołowiec.

Daianu, D. 2000. South-Eastern Europe Revisited? Can economic decline be stopped?, „Occasional Papers”, nr 21.

Dedić, J. 2003. Discrimination in Granting Slovenian Citizenship, [w:] J. Dedić, V. Jalušić, J. Zorn, The Erased. Organized Innocence and the Politics of Exclusion, Mirovni Institut, Ljubljana.

Dougherty, J.E., Pfaltzgraff, Jr., R.L. 1996, Contending Theories of International Relations. A Comprehensive Survey, Longman, New York.

Drakulić, S. 2006. Oni nie skrzywdziliby nawet muchy. Zbrodniarze wojenni przed Trybunałem w Hadze, Wydawnictwo W.A.B., Warszawa.

Dyras, M. 2009. Re-inkarnacje narodu. Chorwackie narracje tożsamościowe w latach dziewięćdziesiatych XX wieku, Wydawnictwo UJ, Kraków.

Fukuyama, F. 2012. Historia ładu politycznego. Od czasów przedludzkich do rewolucji francuskiej, Dom Wydawniczy Rebis, Poznań.

Garlicka, A. 1983. Bałkany a Europa w XIXi XX w., [w:] Dziesięć wieków Europy. Studia z dziejów kontynentu, J. Żarnowski (red.), Wydawnictwo Czytelnik, Warszawa 1983.

Gołembski, F. 1982. Bałkany. Determinanty stabilności, Polski Instytut Spraw Międzynarodowych, Warszawa. Hamourtziadou, L. 2002. The Bosniaks: from nation to threat, ,Journal of Southern Europe and the Balkans”, vol. 4 (2). DOI: https://doi.org/10.1080/1461319022000021594.

Hatzopoulos, P. 2003. 'All that is, is nationalist': Western imaginings of the Balkans since the Yugoslav wars, „Journal of Southern Europe and the Balkans", vol. 5 (1). DOI: https://doi.org/10.1080/1461319032000062633.

Huntington, S.P. 2004. Zderzenie cywilizacji i nowy ksztalt ładu światowego, Wydawnictwo Muza, Warszawa. Jackson, R. 2011, Suwerenność. Ewolucja idei, Wydawnictwo Sic!, Warszawa.

Jacobsen, H.A. 2000. Imperatyw pokoju. Polityka i wojna w XX wieku, Wydawnictwo Poznańskie, Poznań.

Jačov, M. 2005. Europa Środkowowschodnia a zagrożenie osmańskie od XV do XVII wieku, [w:] Europa Środkowowschodnia od X do XVIII wieku -jedność czy różnorodność?, K. Baczkowski, J. Smołucha (red.), Wydawnictwo Towarzystwa Naukowego „Societas Vistulana”, Kraków.

Jakubowski, M.N. 2001. Historia a filozofia historii w koncepcji Hegla, „Filo-Sofija”, nr 1.

Jelavich, B. 2005. Historia Bałkanów, cz. I. Wiek XVIII i XIX, Wydawnictwo UJ, Kraków.

Jelavich, B. 2005. Historia Bałkanów, cz. II. Wiek XX, Wydawnictwo UJ, Kraków.

Jezernik, B. 2007. Dzika Europa. Bałkany w oczach zachodnich podróżników, Towarzystwo Autorów i Wydawców Prac Naukowych Universitas, Kraków. 
Joffe, J. 1992. Spóźnione „tak”, „Gazeta Wyborcza” 23.09.

Judah, T. 2000. Kosovo. War and Revenge, Yale University Press, New Haven-London.

Judah, T. 2009. The Serbs, Yale University Press, New Haven.

Kadare, I. 2001. The Balkans: Truths and untruths, [w:] The southern Balkans: perspectives from the region, D. Triantaphyllou (red.), Institute for Security Studies of Western European Union, Paris.

Kaltsounis, T. 2010. The Democratization of Albania. Democracy from Within, Palgrave Macmillan, New York 2010.

Kaplan, R.D. 2000. Why the Balkans Demand Amorality, [w:] Kosovo. Contending Voices on Balkan Interventions, W.J. Buckley (red.), Wm. B. Eerdmans Publishing Company, Cambridge.

Kissinger, H.A. 2000. Doing Injury to History, [w:] Kosovo. Contending Voices on Balkan Interventions, W.J. Buckley (red.), Wm. B. Eerdmans Publishing Company, Cambridge.

Kollander, P. 2004, The Civil War in Former Yugoslavia and the International Intervention, [w:] Reflections on the Balkan Wars. Ten Years After the Break-Up of Yugoslavia, J.S. Morton, R.C. Nation, P.C. Forge, S. Bianchini (red.), Palgrave Macmillan, New York.

Koseski, A. 2002. W bałkańskim tyglu, Wyższa Szkoła Humanistyczna im. Aleksandra Gieysztora w Pułtusku, Pułtusk.

LeBor, A. 2003. Milosevic. A Biography, Bloomsbury Publishing, London.

Libal, M. 2002. Ethnic Conflict in the Balkans and in the Caucasus: Some General Considerations, „Southeast European and Black Sea Studies", vol. 2 (2). DOI: https://doi.org/10.1080/14683850208454687.

Lubonja, F.T. 1999. Spojrzenie Skanderbega, „Gazeta Wyborcza” 3-5.04.

Lubonja, F. 2000. Reinventing Skenderbeg: Albanian Nationalism and NATO Neocolonialism, [w:] Kosovo. Contending Voices on Balkan Interventions, W.J. Buckley (red.), Wm. B. Eerdmans Publishing Company, Cambridge.

Luttwak, E. N. 2000. Give War a Chance, [w:] Kosovo. Contending Voices on Balkan Interventions, W.J. Buckley (red.), Wm. B. Eerdmans Publishing Company, Cambridge.

Malcolm, N. 2002, Kosovo. A Short History, Pan Books, London.

Malcolm, N. 2006. Is the Muslim conversion of Albanians the main cause of the estrangement between Slavs and Albanians?, [w:] Kosovo. Contending Voices on Balkan Interventions, W.J. Buckley (red.), Wm. B. Eerdmans Publishing Company, Cambridge.

Mazower, M. 2000. The Balkans. From the End of Byzantium to the Present Day, Phoenix Press, London.

Millar, S. 2011. Odsiecz wiedeńska 1683, Osprey Publishing, Poznań.

Mucha, J. 1996. Konflikt etniczny jako typ konfliktu społecznego, [w:] Konflikty etniczne. Źródta - Typy Sposoby rozstrzygania, I. Kabzińska-Stawarz, S. Szynkiewicz (red.), Instytut Archeologii i Etnologii Polskiej Akademii Nauk, Warszawa.

Muś, J. 2013. Bośnia i Hercegowina. Etnopolityczne podziały i ich uwarunkowania, Wydawnictwo KUL, Lublin.

Myśliwski, W. 2013. Ostatnie rozdanie, Wydawnictwo Znak, Kraków.

Nobelprize.org. The Official Web Site of the Nobel Prize, The Nobel Peace Prize 1971, Willy Brandt, Acceptance Speech, http://www.nobelprize.org/nobel_prizes/peace/laureates/1971/brandt-acceptance. html (dostęp: 15.07.2016).

Olchowski, J., Pawłowski, K. 2009. Region Europy Południowo-Wschodniej, [w:] Regiony w stosunkach międzynarodowych, A. Dumała, H. Dumała, I. Topolski (red.), Wydawnictwo UMCS, Lublin.

O’Shea, S. 2009. Morze wiary. Islam i chrześcijaństwo w świecie śródziemnomorskim doby średniowiecza, Dom Wydawniczy Rebis, Poznań.

Paruch, W., Chmura, J. 2012. Kiedy etnos stat się demosem: uwarunkowania historyczne głównego podziału socjopolitycznego w państwach postjugosłowiańskich, [w:] Systemy polityczne państw bałkańskich, T. Bichta, M. Podolak (red.), Wydawnictwo UMCS, Lublin.

Pavlowitch, S.K. 1999, Yugoslavia: the failure of a success, „Journal of Southern Europe and the Balkans”, vol. 1 (2). DOI: https://doi.org/10.1080/14613199908413997. 
Pavlowitch, S.K. 2000. Europe and the Balkans in a historical perspective, 1804-1945, „Journal of Southern Europe and the Balkans", vol. 2 (2).

Popovic, S. 2006. Milošević's motiveless malignancy, [w:] War and Change in the Balkans. Nationalism,

Conflict and Cooperation, B.K. Blitz (red.), Cambridge University Press, Cambridge.

Ratcliffe, S. 2011, Oxford Treasury of Sayings \& Quotations, Oxford University Press, Oxford.

Schwartz, S. 2000. Kosovo: Background to a War, Anthem Press, London.

Sell, L. 2002. Slobodan Milosevic and the Destruction of Yugoslavia, Duke University Press Books, Durham-London.

Shaw, M.N. 2006. Prawo międzynarodowe, Książka i Wiedza, Warszawa.

Silber, L., Little, A. 1997. Yugoslavia. Death of a Nation, Penguin Books, New York.

Simic, P. 2001. Do the Balkans exists?, [w:] The southern Balkans: perspectives from the region, D. Triantaphyllou (red.), Institute for Security Studies of Western European Union, Paris.

Sur, S. 2012. Stosunki międzynarodowe, Wydawnictwo Akademickie Dialog, Warszawa.

Szacki, J. 1981. Historia myśli socjologicznej, cz. I i II, Państwowe Wydawnictwo Naukowe, Warszawa.

Tanty, M. 2003, Bałkany w XX wieku. Dzieje polityczne, Książka i Wiedza, Warszawa.

Tochman, W. 2002. Order uczuć pierwszej klasy. Rozmowa z Tadeuszem Mazowieckim, „Gazeta Wyborcza” (,Magazyn”) 11.04.

Todorova, M. 2000. The Balkans: From Invention to Intervention, [w:] Kosovo. Contending Voices on Balkan Interventions, W.J. Buckley (red.), Wm. B. Eerdmans Publishing Company, Cambridge.

Todorova, M. 2008. Batkany wyobrażone, Wydawnictwo Czarne, Wołowiec.

Tziampiris, A. 2003. The name dispute in the Former Yugoslav Republic of Macedonia after the signing of the Interim Accord, [w:] Athens-Skopje: An Uneasy Symbiosis (1995-2002), E. Kofos, V. Vlasidis (red.), Eliamep, Athens.

Uvalic, M. 2001, Regional Co-operation in Southeast Europe, „Journal of Southeast European and Black Sea Studies", vol. 1 (1).

Veremis, T. 2001. The End of History - American Views on the Balkans, „Southeast European and Black Sea Studies", vol. 1 (2).

Waldenberg, M. 2003. Rozbicie Jugosławii. Od separacji Stowenii do wojny kosowskiej, Wydawnictwo Naukowe Scholar, Warszawa.

Walkiewicz, W. 2000. Jugosławia. Byt wspólny i rozpad, Wydawnictwo Trio, Warszawa.

Wasilewski, T.W., Felczak, W. 1985. Historia Jugosławii, Ossolineum, Wrocław.

Weir, W. R. 2005. Przełomowe momenty w historii konfliktów zbrojnych, Wydawnictwo Amber, Warszawa.

Wierzbicki, B. 2008. Uznanie państw, [w:] Prawo międzynarodowe. Materiały do studiów, B. Wierzbicki (red.), Wydawnictwo Temida 2, Białystok.

Zimmermann, A., Stahn, C. 2001. Yugoslav Territory, United Nations Trusteeship or Sovereign State? Reflections on the Current and Future Legal Status of Kosovo, „Nordic Journal of International Law”, vol. 70 (4). DOI: https://doi.org/10.1023/A:1014857531228; https://doi.org/10.1163/15718100120296719.

Žarkov, D. 2007. The Body of War. Media, Ethnicity, and Gender in the Break-up of Yugoslavia, Duke University Press Books, Durham-London. 


\section{ANTE BELLUM: HISTORICAL CONDITIONINGS OF DISINTEGRATION PROCESSES IN THE TERRITORY OF THE SOCIALIST FEDERAL REPUBLIC OF YUGOSLAVIA AND ITS SUCCESSOR STATES AFTER THE COLD WAR}

Abstract: The article presents broad historical conditionings of the disintegration processes that occurred after the end of the Cold War in the territory of the former Socialist Federal Republic of Yugoslavia. It argues that in the last decade of the 20th century Yugoslav nations initialized a 'return to history', visible in their efforts to 'reverse' unfavorable historical processes, complete 'unfinished' state-building processes and unify the territories inhabited today or in the past by given ethnic groups. It indicates the centuries-old rule of the Ottoman Turkey in the Balkans, unresolved territorial disputes, the periods of open, armed confrontation between Balkan people, negative experiences of mutual relations and common statehood as well as a recurring policy of external interventionism and paternalism in 19th and 20th century. It claims that a complicated history of the Balkan region was not the main reason for the disintegration of SFRY, but it nevertheless contributed significantly to the breakup of the Yugoslav federation and the outbreak of armed conflicts in the 90s. It concludes that the 'unfinished history' continues to contribute to the political disintegration and instability of the Balkans, as well as to a serious dysfunctionality of some of the post-Yugoslav states.

Keywords: History of the Balkans, disintegration of the Socialist Federal Republic of Yugoslavia, national-forming and state-building processes in the Balkans, external interventions in the Balkan region

\section{BIOGRAM}

Konrad Pawłowski, adiunkt w Zakładzie Stosunków Międzynarodowych Wydziału Politologii Uniwersytetu Marii Curie-Skłodowskiej w Lublinie. Zainteresowania badawcze koncentruje wokół problematyki procesu pokojowego i ewolucji stosunków międzynarodowych w regionie Europy Południowo-Wschodniej. Autor kilkudziesięciu artykułów naukowych oraz monografii Kosowo. Konflikt i interwencja, Lublin 2008. Kontakt e-mail: konrad.pawlowski@poczta.umcs.lublin.pl. 